\title{
APPRAISAL OF THE PELICAN RIVER SAND-PLAIN AQUIFER, WESTERN MINNESOTA
}

WATER RESOURCES DIVISION

U. S. GEOLOGICAL SURVEY

OPEN-FILE REPORT 82-347

PREPARED IN COOPERATION WITH THE MINNESOTA DEPARTMENT OF NATURAL RESOURCES, THE WESTERN MINNESOTA RESOURCES CONSERVATION AND DEVELOPMENT COMMISSION, AND THE PELICAN RIVER SANDS STEERING COMMITTEE

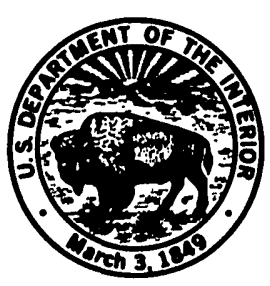



UNITED STATES

DEPARTMENT OF THE INTERIOR

GEOLOGICAL SURVEY

\section{A PPRAISAL OF THE PELICAN RIVER SAND-PLAIN AQUIFER, WESTERN MINNESOTA}

By R. T. Miller

Open-File Report 82-347

Prepared in cooperation with the

MINNESOTA DEPARTMENT OF NATURAL RESOURCES, the

WESTERN MINNESOTA RESOURCES CONSERVATION

AND DEVELOPMENT COMMISSION, and the

PELICAN RIVER SANDS STEERING COMMITTEE

St. Paul, Minnesota

August 1982 
Page

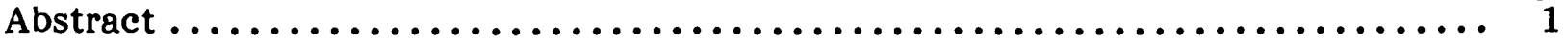

Introduction $\ldots \ldots \ldots, \ldots, \ldots, \ldots, \ldots, \ldots, \ldots, \ldots, \ldots, \ldots, \ldots, \ldots, \ldots, \ldots, 1$

Purpose and scope $\ldots \ldots \ldots \ldots \ldots \ldots \ldots \ldots \ldots \ldots \ldots \ldots \ldots \ldots \ldots, \ldots \ldots, 1$

Location and description of study area $\ldots \ldots \ldots \ldots \ldots \ldots \ldots \ldots \ldots \ldots \ldots, 2$

Previous investigations $. . \ldots \ldots \ldots \ldots \ldots \ldots \ldots \ldots \ldots \ldots \ldots \ldots \ldots, 2$

Test-hole and well-numbering system $\ldots \ldots \ldots \ldots \ldots \ldots \ldots \ldots \ldots \ldots \ldots, 2$

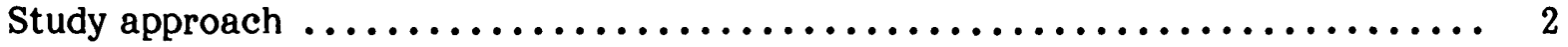

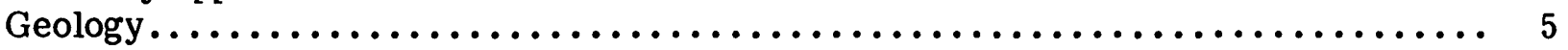

Ground-water hydrology $. \ldots \ldots \ldots \ldots \ldots \ldots \ldots \ldots \ldots \ldots \ldots \ldots \ldots \ldots \ldots,{ }^{5}$

Conceptual model of ground-water flow $\ldots \ldots \ldots \ldots \ldots \ldots \ldots \ldots \ldots \ldots \ldots, 5$

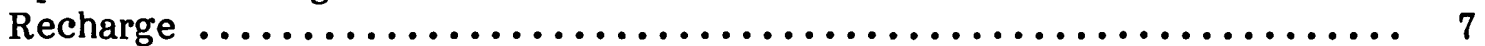

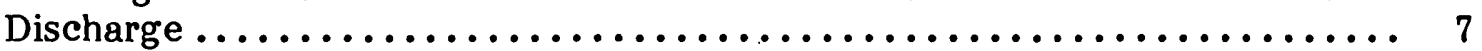

Hydraulic characteristics of the surficial aquifer $\ldots \ldots \ldots \ldots \ldots \ldots \ldots \ldots, 9$

Theoretical well yields $. . \ldots \ldots \ldots \ldots \ldots \ldots \ldots \ldots \ldots \ldots \ldots \ldots \ldots \ldots \ldots \ldots, 11$

Estimating transmissivity from specific capacity $\ldots \ldots \ldots \ldots \ldots \ldots \ldots \ldots \ldots . \ldots \ldots 12$

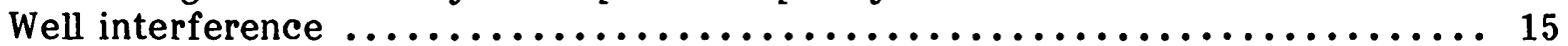

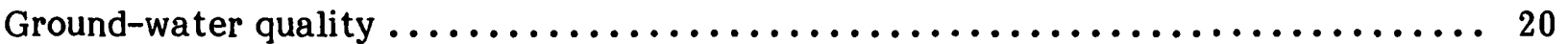

Simulation of surficial-aquifer flow system $\ldots \ldots \ldots \ldots \ldots \ldots \ldots, \ldots \ldots \ldots, \ldots, 22$

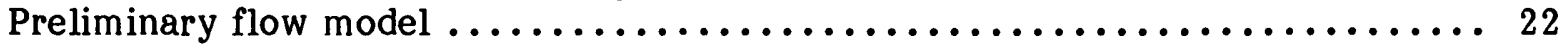

Analytical model $\ldots \ldots \ldots \ldots \ldots \ldots \ldots \ldots \ldots \ldots \ldots \ldots \ldots \ldots \ldots \ldots \ldots, 22$

Hypothetical pumping effects on the Pelican River, Pelican Rapids

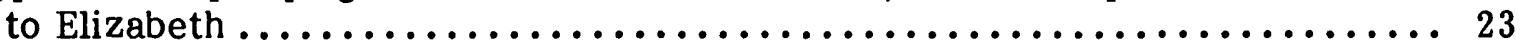

Numerical model $\ldots \ldots \ldots \ldots \ldots \ldots \ldots \ldots \ldots \ldots \ldots \ldots \ldots \ldots \ldots \ldots \ldots \ldots . \ldots \ldots, 27$

Description of model $\ldots \ldots \ldots \ldots \ldots \ldots \ldots \ldots \ldots \ldots \ldots \ldots \ldots \ldots \ldots, 27$

Scambler model $\ldots \ldots \ldots \ldots \ldots \ldots \ldots \ldots \ldots \ldots \ldots \ldots \ldots \ldots, \ldots \ldots, 28$

Detroit Lakes model $. \ldots \ldots \ldots \ldots \ldots \ldots \ldots \ldots \ldots \ldots \ldots \ldots \ldots \ldots, \ldots \ldots$

Model calibration $\ldots \ldots \ldots \ldots \ldots \ldots \ldots \ldots \ldots \ldots \ldots \ldots \ldots \ldots \ldots \ldots, 30$

Analysis of hypothetical pumping $\ldots \ldots \ldots \ldots \ldots, \ldots, \ldots, \ldots, \ldots, \ldots, \quad 32$

Scambler model $\ldots \ldots \ldots \ldots \ldots \ldots \ldots \ldots \ldots \ldots \ldots \ldots \ldots \ldots \ldots \ldots, 32$

Detroit Lakes model $\ldots \ldots \ldots \ldots \ldots \ldots \ldots \ldots \ldots \ldots \ldots \ldots \ldots \ldots \ldots, 34$

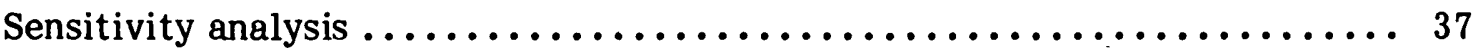

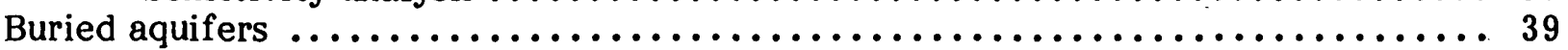

Summary $. . \ldots \ldots \ldots \ldots \ldots \ldots \ldots \ldots \ldots \ldots \ldots \ldots \ldots \ldots \ldots \ldots \ldots \ldots \ldots,{ }^{39}$

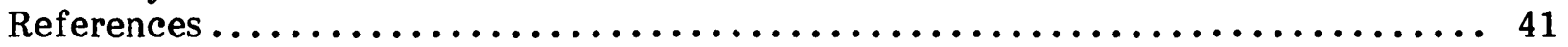

\section{ILLUSTRATIONS}

Plate 1. Hydrogeologic maps of the surficial-outwash aquifer, Pelican River sand-plain study, Minnesota $\ldots \ldots \ldots \ldots \ldots \ldots \ldots$ in back

2. Numerical-model analysis of surficial-outwash aquifer,

Pelican River sand-plain study, Minnesota ............... in back

3. Sensitivity maps for numerical-model input parameters,

Pelican River sand-plain study, Minnesota $\ldots \ldots \ldots \ldots \ldots \ldots$ in back 


\section{ILLUSTRATIONS}

Figure 1. Map showing location and extent of study are $\ldots \ldots \ldots \ldots \ldots \ldots \ldots . \ldots$

Figure 1. Map showing location and extent of study area $\ldots \ldots \ldots \ldots \ldots \ldots \ldots$

2. Graph showing test-hole and well-numbering system $\ldots \ldots \ldots \ldots \ldots \ldots$

3. Idealized diagram illustrating source and discharge areas for ground water ................................ 6

4. Example hydrograph showing method of estimating recharge during the spring to the surficial aquifer................. 8

5. Graph showing range and average of particle-size distribution curves of 72 samples from test holes ................... 10

6. Graph showing estimated maximum yield of wells based on saturated thickness and transmissivity ................. 13

7. Graph showing relation between specific capacity and the coefficient of transmissivity for selected pumping periods

8. Schematic profile illustrating effects of nearby wells and hydrologic boundaries on drawdown $\ldots \ldots \ldots \ldots \ldots \ldots \ldots \ldots \ldots$

9. Graph showing theoretical relation of drawdown to distance from a pumped well and time of pumping for a pumping

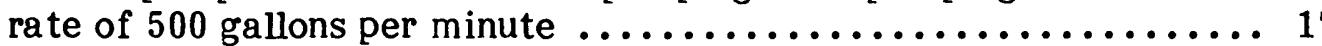

10. Graph showing theoretical curves for adjustment of drawdown in unconfined aquifers $\ldots \ldots \ldots \ldots \ldots \ldots \ldots \ldots \ldots \ldots \ldots$

11. Diagram showing suitability of ground water for irrigation in terms of sodium-adsorption ratio and specific conductance....... 21

12. Map showing location, discharge, and percentage of water derived from pumping wells along the Pelican River........... 24

13. Map showing flow of the Pelican River and quantity of hypothetical pumpage derived from streamflow $\ldots \ldots \ldots \ldots \ldots \ldots 26$

14. Idealized hydrologic section showing locations of observation wells for the confined-aquifer pumping test

\section{TABLES}

Table 1. Results of aquifer tests in the Pelican River sand plain $\ldots \ldots \ldots \ldots \ldots$

2. Values of hydraulic conductivity for surficial outwash in the

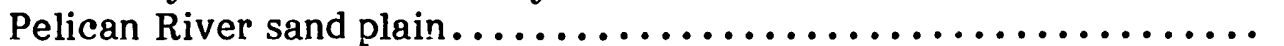




\section{TABLES}

Table 3. Magnitude and frequency of annual low flows for the Pelican

4. Model calculated water budget

5. Percentages of total ground-water sources and discharges for steady-state simulations for the scambler numerical model ....... 34

6. Percentages of total ground-water sources and discharges for steady-state simulations for the Detroit Lakes numerical model

\section{CONVERSION FACTORS}

\section{Multiply inch-pound unit}

inch (in)

foot $(\mathrm{ft})$

mile (mi)

acre

acre-foot (acre-ft)

square mile $\left(\mathrm{mi}^{2}\right)$

foot per day ( $\mathrm{ft} / \mathrm{d})$

foot squared per day $\left(\mathrm{ft}^{2} / \mathrm{d}\right)$

cubic foot per second $\left(\mathrm{ft}^{3} / \mathrm{s}\right)$

gallon (gal)

gallon per minute (gal/min)

gallon per minute per foot

$(\mathrm{gal} / \mathrm{min}) / \mathrm{ft}$
By

25.40

0.3048

1.609

0.4047

0.001233

2.590

0.3048

0.0929

0.02832

3.785

0.06309

0.207
To obtain SI (metric) unit

millimeter $(\mathrm{mm})$

meter $(\mathrm{m})$

kilometer $(\mathrm{km})$

hectare (ha)

cubic hectometer $\left(\mathrm{hm}^{3}\right)$

square kilometer $\left(\mathrm{km}^{2}\right)$

meter per day $(\mathrm{m} / \mathrm{d})$

meter squared per day $\left(\mathrm{m}^{2} / \mathrm{d}\right)$

cubic meter per second $\left(\mathrm{m}^{3} / \mathrm{s}\right)$

liter (L)

liter per second $(\mathrm{L} / \mathrm{s})$

liter per second per meter

$(\mathrm{L} / \mathrm{s}) / \mathrm{m}$ 


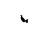




\title{
APPRAISAL OF THE PELICAN RIVER SAND-PLAIN AQUIFER, WESTERN MINNESOTA
}

By R. T. Miller

\begin{abstract}
The Pelican River sand-plain area includes approximately 200 square miles of outwash deposits in parts of Becker, Otter Tail, and Clay Counties in west-central Minnesota. Saturated thickness of the outwash is as much as 140 feet and yields of properly constructed wells locally may exceed 1,200 gallons per minute.

Recharge to the outwash from snowmelt and rain ranged from 3.2 to 6.1 inches during 1979-80. Discharge from the aquifer, as base flow of the Pelican River, averaged 2.0 inches during 1979-80. Evapotranspiration is 22.4 inches per year. The chemical quality of ground water is suitable for irrigation, as measured by sodium-adsorption ratios, but locally high concentrations of calcium, magnesium, and bicarbonate may cause clogging of well screens.

Mathematical models of parts of the ground-water-flow system indicate that lake levels and streamflow may decline because of pumping wells. The exact water-level decline depends on the total number of wells, pumping rates, location of pumping wells with respect to one another and to surface-water bodies, duration of pumping, and the quantity of ground-water recharge. Sensitivity analyses of the models indicates that additional data on hydraulic conductivity, evapotranspiration, and recharge may increase the reliability of model results.
\end{abstract}

Buried aquifers are known to be present in the area. Aquifer-test results showed that pumping from a buried aquifer had no effect on water levels in the unconfined aquifer.

\section{INTRODUCTION}

\section{Purpose and Scope}

The Pelican River sand plain is underlain by irrigable soils, but little is known about the availability and chemical suitability of ground water for irrigation and other uses. In 1978, the U.S. Geological Survey, in cooperation with the Minnesota Department of Natural Resources, began an appraisal of water in the surficial aquifer of the Pelican River sand plain. The objectives were to (1) determine the quantity and quality of water available from the surficial and buried aquifers in the Pelican River sand plain, (2) analyze the effects of developing the surficial aquifer on ground-water storage and surface water, and (3) evaluate the effects of pumping from buried aquifers on water storage in both the buried and surficial aquifers. 


\section{Location and Description of Study Area}

The Pelican River sand-plain study area is in west-central Minnesota, 55 miles east of the North Dakota border. It encompasses about $200 \mathrm{mi}^{2}$ in parts of Becker, Otter Tail, and Clay Counties, with 95 percent of its total area equally divided between Becker and Otter Tail Counties (fig. 1). The general shape is elongate north-south, with the southern boundary near Elizabeth and the northern boundary near Richwood.

Summers are short and mild; winters are long and severe. The average annual temperature is $39.2^{\circ} \mathrm{F}$; monthly averages range from $5^{\circ} \mathrm{F}$ in January to $69.5^{\circ} \mathrm{F}$ in July. Nor mal annual precipitation is 23.57 inches, ranging from 0.65 inches in February to 3.95 inches in both June and August. A large part of the precipitation, 68.8 percent, is concentrated between May and September (Larson, 1976).

The area is in the western lake section of the Central Lowland province (Fenneman, 1938), lying in a broad belt of hilly lake country that trends north-south through westcentral Minnesota. Approximately 20 percent is covered by water. Lakes range in size from about 3,000 acres, such as Detroit Lake, Lake Sallie, Lake Melissa, Prairie Lake, and Pelican Lake, to many small unnamed lakes, potholes, and marshes. Total relief is 275 feet, with altitudes ranging from 1,475 feet in the hills near Richwood to 1,200 feet in the Pelican River valley south of Elizabeth.

\section{Previous Investigations}

The first description of the hydrology was by Upham (1888) in his summary of the geology and natural history of Otter Tail and Becker Counties. Another general discussion of the hydrology is contained in Allison's (1932) study of the geology and water resources of northwestern Minnesota. A more detailed analysis of the water resources was made by Winter and others (1969). More localized and detailed work concerning the interaction of lakes with ground water was made by Mann and McBride (1972), McBride and Pfannkuch (1975), and Larson, McBride, and Wolf (1975). The principal glacial features were described by Leverett (1932) and reinterpreted by Wright and Ruhe (1965).

\section{Test-Hole and Well-Numbering System}

The method of numbering wells and test holes is based on the U.S. Bureau of Land Management's system of subdivision of public lands (township, range, and section). The first segment of a well or test-hole number indicates the township north of the base line; the second, the range west of the principal meridian; and the third, the section in which the well or test hole is located. The uppercase letters, A, B, C, and D following the section number locate the well within the section. The first letter denotes the 160-acre tract, the second the 40-acre tract, and the third, the 10-acre tract, as shown in figure 2. The letters are assigned in a counterclockwise direction, beginning in the nor theast quarter. Within one 10-acre tract, successive well numbers, beginning with 1 , are added as suffixes. As shown in figure 2, the number 134N43W14ADC1 indicates the first well or test hole located in the SW $\frac{1}{4} \mathrm{SE}^{\frac{1}{4}} \mathrm{NE} \frac{1}{4}$, sec.14, T. 134 N., R. $43 \mathrm{~W}$.

\section{Study Approach}

To meet the study objectives, maps of the areal extent and thickness of the surficial aquifer were prepared, and the physical and hydrologic characteristics of the aquifer were determined. Annual recharge and discharge were estimated, and the chemical 


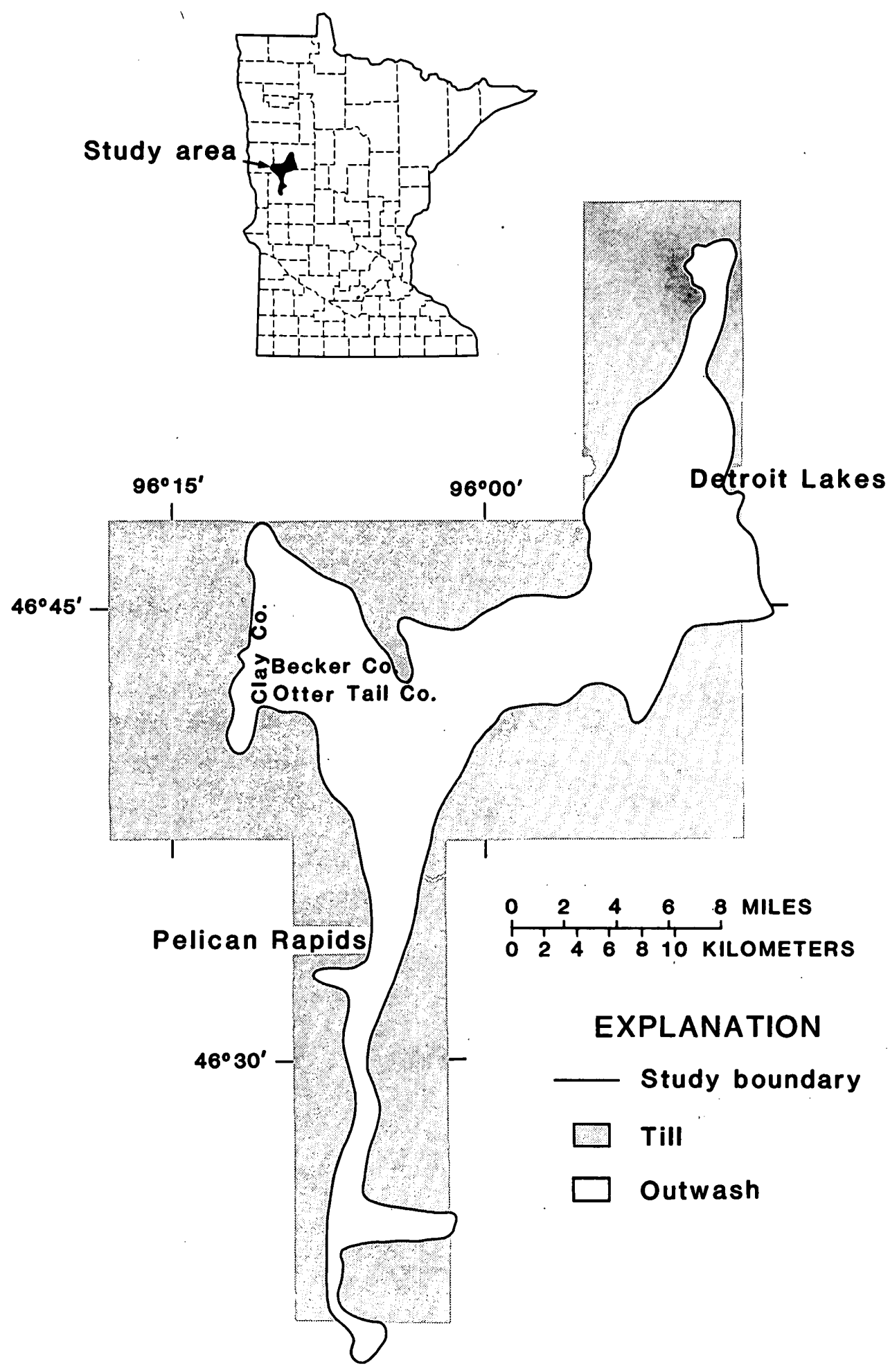

Figure 1.--Location and extent of study area 


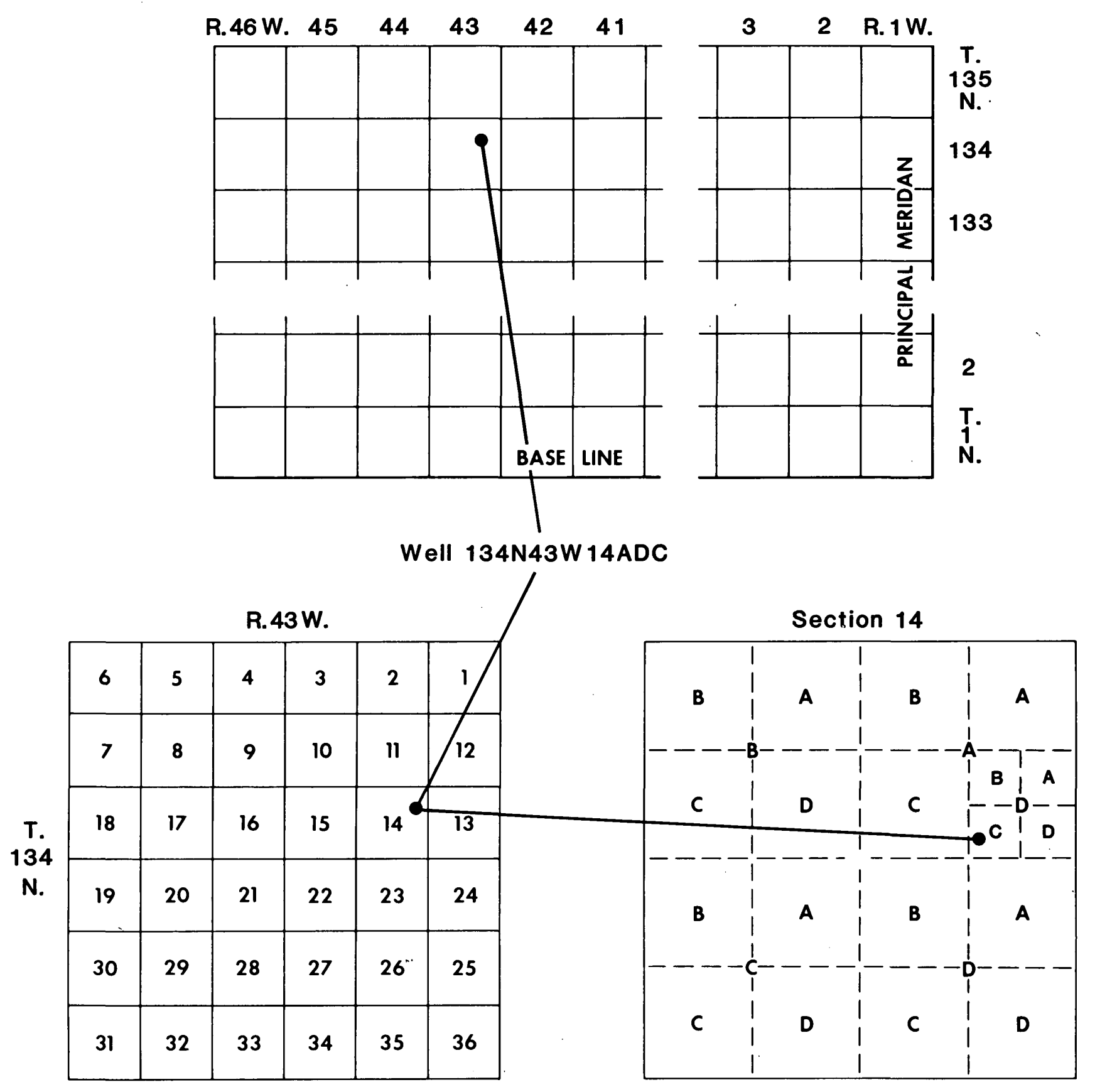

Figure 2.--Test-hole and well-numbering system 
quality of the water was determined. Two areally independent preliminary numerical models were constructed. The model boundaries are similar to those shown on plate 1. Sensitivity analyses were made of hydraulic conductivity. The sensitivity information was then used to aid in drilling additional observation wells. Field data were analyzed to refine the preliminary models, which were then used to determine the probable effects of ground-water development on the system under differing recharge conditions. An analytical model was constructed to examine the effects of ground-water development on flow of the Pelican River south of Pelican Rapids.

\section{GEOLOGY}

Bedrock consists of Precambrian metamorphic rocks, mantled in places by thin patches of Cretaceous sandstone and shale. Drift of Pleistocene age, which covers these rocks, is some of the thickest in Minnesota (Wright and Ruhe, 1965), ranging from 300 to 500 feet thick. The drift represents the Alexandria moraine complex (Wright and Ruhe, 1965) of Wisconsin Glaciation. The complex contains drift of two ice lobes, the older Wadena lobe and the younger Des Moines lobe, which covers most of the area.

The drift is mainly till, an unstratified, unsorted mixture of clay, silt, sand, and gravel, deposited directly by the glacial ice, and outwash consisting of stratified wellsorted sand and gravel, deposited by glacial melt water.

The study area boundary is the contact at the surface between till and outwash (fig. 1). The outwash is as thick as 125 feet in places and is underlain by a gray silty till. The outwash was deposited as the Des Moines Lobe retreated and streams from the melting ice reworked the available sediment. Depressions that form the lakes were created by ice blocks that melted long after retreat of the ice lobes (Wright and Ruhe, 1965).

\section{GROUND-WATER HYDROLOGY}

\section{Conceptual Model of Ground-Water Flow}

Water in the Pelican River sand plain is contained in pores or openings between rock particles in the drift. The size and orientation of the openings determine how much water is stored and how easily water flows.

Ground water flows in a general direction from source, or recharge, areas to loss, or discharge, areas. The general direction of flow is illustrated by the water-level map A on plate 1. Contours were constructed from water-level averages for 1979 and 1980 in 34 observation wells and lake and river altitudes from 7.5-minute topographic maps.

Ground-water flow is in the direction of decreasing water-level contours; this is shown on plate 1, map A by directional arrows perpendicular to the water-level contours. The general direction of flow is toward the Pelican River and Detroit, Sallie, Melissa, Pelican, and Prairie Lakes. Smaller streams and lakes also serve as discharge areas and can locally affect the direction of flow.

Figure 3 illustrates the conceptual model of recharge and discharge for the Pelican River sand plain. 


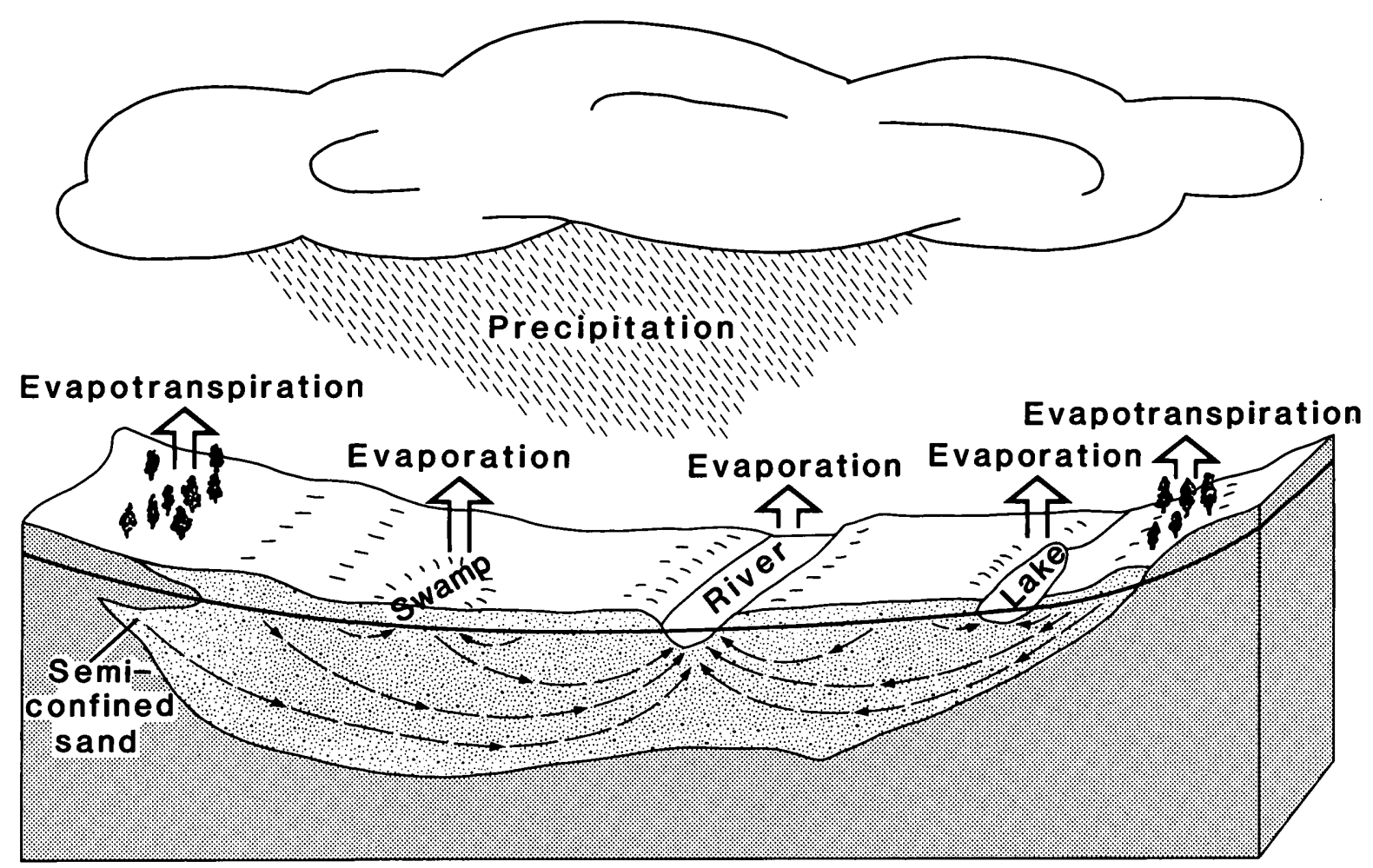

EXPLANATION

- Water table
$\longleftarrow-\begin{aligned} & \text { Direction of ground Sand } \\ & \text { water flow }\end{aligned}$

Figure 3.--Idealized diagram illustrating source and discharge areas for ground water 


\section{Recharge}

The major source of water in the surficial aquifer is precipitation. Areal recharge from precipitation can be estimated from ground-water hydrographs. Figure 4 shows a plot of water level in a well versus time and illustrates a method for calculating recharge. The graph shows that recharge is greatest during spring and that water levels generally decline through summer and early fall. Small rises may occur in late fall, depending on the rainfall and whether or not the ground is frozen. Using this technique, areal recharge in spring was calculated to range 3.7 to 6.1 inches in 1979 and from 3.1 to 5.9 inches in 1980 .

Another source of water in the surficial aquifer is ground water that moves horizontally across the boundary between the outwash and the till. Water in the till moves slowly due to its low hydraulic conductivity, and, consequently, its contribution to recharge is small. Recharge across the outwash-till boundary was estimated from Darcy's Law with data from wells located near or at the boundary (Davis and DeWiest, 1966). Hydraulic conductivity of the till used in all the calculations was $9.35 \times 10^{-3}$ feet per day (Norvitch and others, 1974). The average rate of woter entering the area across the boundary per linear foot was calculated as $1.5 \times 10^{-3}$ cubic feet per day. This converts to an average contribution of 0.20 inch per year from the till across this entire boundary during both 1979 and 1980.

Ground water also enters the area from outwash that has been buried by younger till (Larson and others, 1975). Therefore, unlike the outwash-till contact described above, the outwash here extends beneath the till and forms a buried boundary (fig. 3 ). Because the physical boundaries have been defined as the contact between the till and outwash at the surface, the buried outwash is considered to be outside the boundary. Even though recharge enters the area through the buried outwash, and even though the water moves faster across this boundary than across the surficial boundary because of the higher hydraulic conductivity of the buried sand, the boundary length is short and the contribution to total recharge is small. Total contribution to recharge was calculated from Darcy's Law and from water-level data near the buried boundary as in the method previously described. The avergge rate of water flow from the buried outwash into the area was calculated to be $0.1 \mathrm{ft}^{3} / \mathrm{d}$. This converts to 0.17 inch per year across the buried boundary in both 1979 and 1980 .

\section{Discharge}

Ground water is discharged from the area naturally and artificially. Natural discharge is to streams, lakes, swamps, and marshes, and from evaporation and transpiration. Artificial discharge is pumpage.

Most of the ground water discharged is by evapotranspiration, which is a combination of direct evaporation of soil moisture and surface water and of moisture transpired by plants. If ground water is near land surface, it can be evaporated directly from soil kept moist by capillary action. Plants having roots that extend to the water table also remove water from the ground-water reservoir by transpiration. Swamps, marshes, lakes, and streams, where there is abundant plant life and the water table is at or near the surface, are areas where large quantities of ground water are evaporated and transpired. The long-term average annual evapotranspiration 22.4 inches (Winter and others, 1969). Evapotranspiration is generally negligible where ground-water levels are more than 5 feet below land surface. Ground-water evapotranspiration can be reduced by lowering water levels through pumping. 

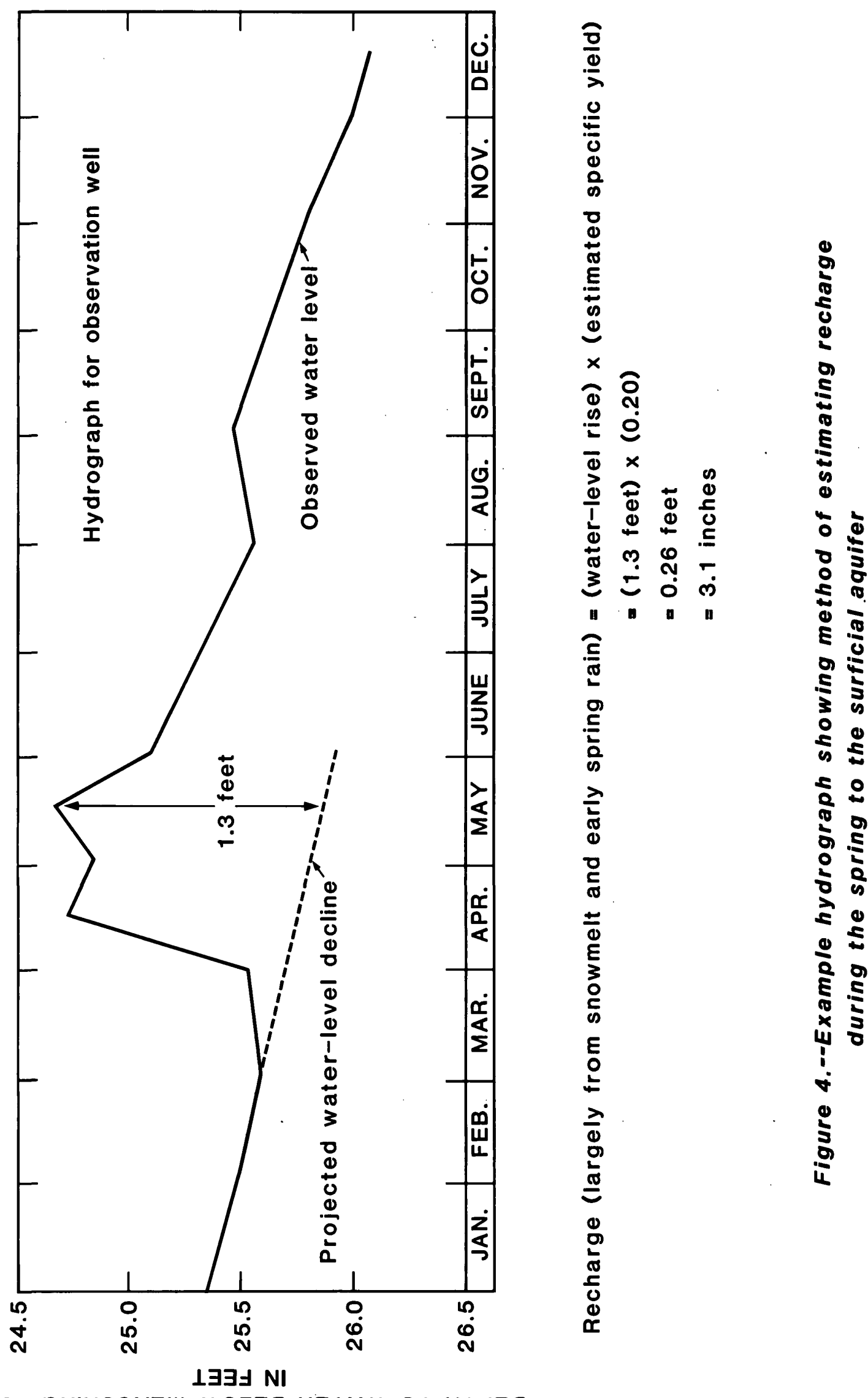

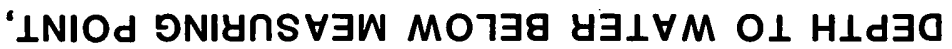




\section{Hydraulic Characteristics of the Surficial Aquifer}

To estimate the rate and magnitude of water-table declines resulting from withdrawals, the transmissivity and specific yield must be known. Transmissivity is estimated by multiplying saturated thickness by hydraulic conductivity.

Saturated thickness of an unconfined aquifer is defined as the vertical distance between the water table and the bottom of the aquifer. Saturated thickness of the surficial aquifer ranges from a few feet to more than 100 feet (pl. 1, map B). Saturated thickness is more than 100 feet north and west of Pelican Lake and along the Pelican River from Pelican Rapids south to Erhard (pl. 1, map B). Elsewhere, saturated thickness generally ranges from 20 to 60 feet. Saturated thickness was determined by private well drillers' logs and test holes, as described by Miller (1980).

Hydraulic conductivity and specific yield were determined from data collected during three aquifer tests. Results of the tests are summarized in table 1 . Hydraulic conductivities are representative only in the immediate area of the test. Hydraulic conductivities were estimated at other locations from Reeder (1972), Larson (1976), and laboratory analyses of samples collected during test drilling. Selected samples of drill cuttings from test holes in the surficial-sand aquifer were analyzed in the laboratory by sieve analysis for particle-size distribution. The range and average of particle-size distribution is shown graphically in figure 5. Median grain size of most samples ranged from fine to coarse sand, and averages medium sand tending toward coarse sand. The relation of particle-size classification to hydraulic conductivity is shown in table 2. This relation was used to estimate the hydraulic conductivity at 72 test-hole sites. Lower conductivity values in each range were assigned to relatively poorly sor ted material, and higher values were assigned to well-sorted material. Transmissivity was then determined by multiplying the estimated hydraulic conductivity by the saturated thickness (pl. 1, map C).

Table 1.-Results of aquifer tests in the Pelican River sand plain

\begin{tabular}{|c|c|c|c|c|c|c|}
\hline \multirow[b]{2}{*}{ Location } & \multirow[b]{2}{*}{$\begin{array}{l}\text { Length } \\
\text { of test } \\
\text { (hours) }\end{array}$} & \multirow[b]{2}{*}{$\begin{array}{l}\text { Average } \\
\text { pumping } \\
\text { rate } \\
\text { (gal/min) }\end{array}$} & \multicolumn{4}{|c|}{ Aquifer characteristics } \\
\hline & & & $\begin{array}{c}\text { Transmis- } \\
\text { siyity } \\
\left(\mathrm{ft}^{2} / \mathrm{d}\right)\end{array}$ & $\begin{array}{l}\text { Satur- } \\
\text { ated } \\
\text { thick- } \\
\text { ness } \\
\text { (ft) }\end{array}$ & $\begin{array}{l}\text { Average } \\
\text { hydraulic } \\
\text { conduc- } \\
\text { tivity } \\
\text { (ft/d) }\end{array}$ & $\begin{array}{l}\text { Specific } \\
\text { yield }\end{array}$ \\
\hline $\begin{array}{l}138 \text { N } 41 \text { W17DCA } 1 \\
138 N 41 \text { W } 16 C C B 1 \\
138 N 42 \text { W } 25 \text { DAA } 1\end{array}$ & $\begin{array}{r}120 \\
120 \\
14\end{array}$ & $\begin{array}{r}90 \\
115 \\
300\end{array}$ & $\begin{array}{l}7,800 \\
8,250 \\
8,400\end{array}$ & $\begin{array}{l}60 \\
50 \\
40\end{array}$ & $\begin{array}{l}130 \\
165 \\
210\end{array}$ & $\begin{array}{r}0.17 \\
.24 \\
.29\end{array}$ \\
\hline
\end{tabular}

Results from analysis of aquifer tests indicated specific yields ranging from 0.17 to 0.29. Studies of surficial-outwash material by Reeder (1972), Larson (1976), Lindholm (1980), and Myette (U.S. Geological Survey, St. Paul, Minn., written commun., 1981) give similar ranges from 0.15 to 0.25 . 


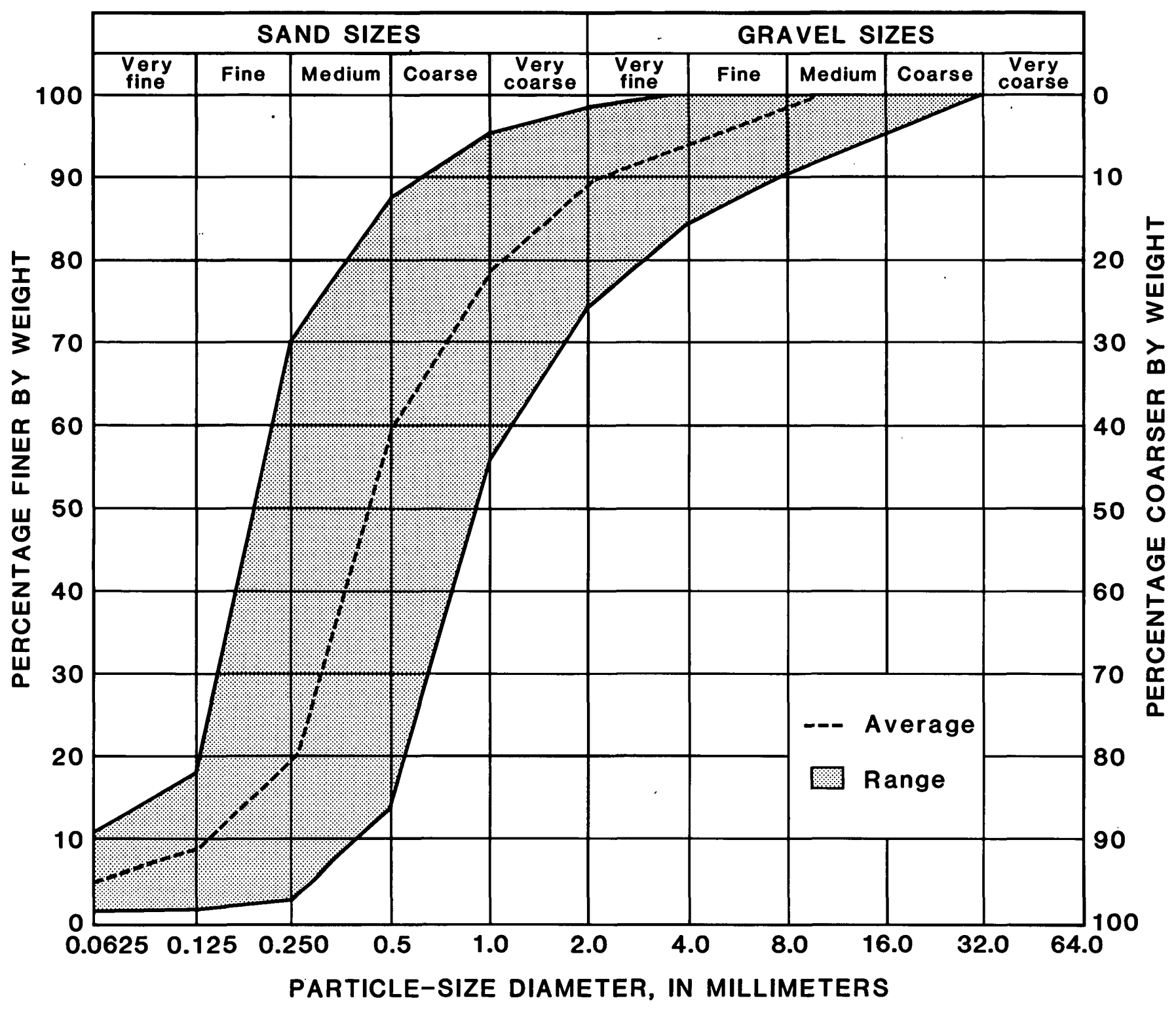

Figure 5.--Range and average of particle-size distribution curves of 72 samples from test holes 


\section{Table 2.-Values of hydraulic conductivity for surficial}

outwash in the Pelican River sand plain

(From Larson, 1976)

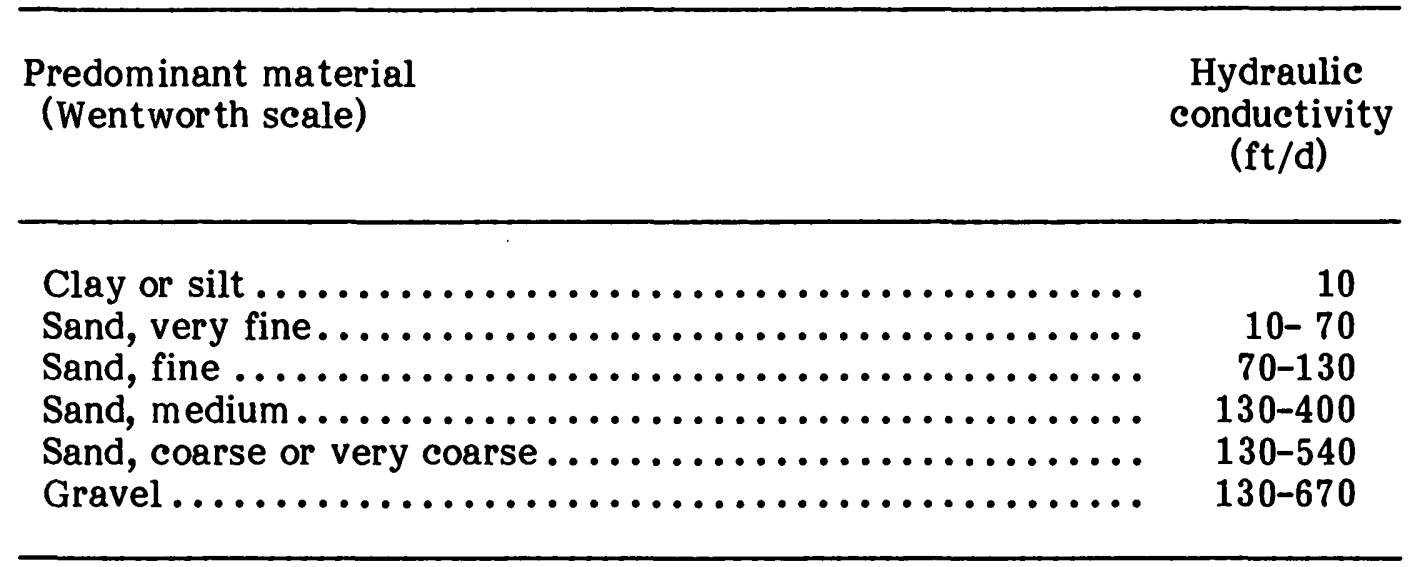

\section{THEORETICAL WELL YIELDS}

The potential yield of an aquifer can be determined through quantitative analysis of the hydraulic properties. Calculations of theoretical optimum yield from properly constructed wells in the Pelican River surficial aquifer were made from the following assumptions.

1. The aquifer is homogeneous and of infinite areal extent.

2. The well is screened through the entire thickness of the aquifer, is 100 percent efficient, and has a diameter of 1.0 foot.

3. The well is pumped continuously for $\mathbf{3 0}$ days, assuming no recharge.

4. Drawdown is two-thirds the original saturated thickness. Theoretically, this corresponds to 90 percent of the maximum yield for unconfined aquifers and is generally accepted as the optimum design specification (E. E. Johnson, Inc., 1966, p. 107-108).

5. No interference from other pumping wells.

Based on these assumptions, the nonequilibrium equations of Theis (1935) and the correction for unconfined aquifers of Jacob (1944) were used to compute individual well yields, which are shown on map D, plate 1 . The map shows only general trends and relative differences in water-yielding capacity. Local exceptions to the well-yield values shown are to be expected because of local variations in the hydraulic properties and the proximity of the well to hydrologic boundaries, such as the edge of the aquifer, lakes, rivers, and other pumping wells.

The areas of highest calculated theoretical yield are generally in areas of highest transmissivity. The highest well yields, $1,200 \mathrm{gal} / \mathrm{min}$ or more, were calculated for the following areas: south of Big Cormorant Lake, west of Pelican Lake, southeast of Detroit Lake, southeast of Turtle Lake, and from Prairie Lake to southwest of Pelican Rapids. 
An estimate of the theoretical maximum yield to a single well can be obtained from figure 6 if saturated thickness and transmissivity at the well site are known. The saturated thickness and transmissivity can be estimated from plate 1 or from the logs of test holes described in Miller (1980). Examples of the use of figure 6 are:

1. From test-hole information, transmissivity is estimated to be $15,000 \mathrm{ft}^{2} / \mathrm{d}$ and saturated thickness 60 feet. What is the hypothetical maximum yield? On figure 6, locate the transmissivity of $15,000 \mathrm{ft}^{2} / \mathrm{d}$ on the horizontal axis. Move up the chart until the $15,000 \mathrm{ft}^{2} / \mathrm{d}$ line crosses the 60 -foot saturated-thickness line from the vertical axis. Read the value of maximum yield to be $900 \mathrm{gal} / \mathrm{min}$.

2. A well is needed to deliver at least $100 \mathrm{gal} / \mathrm{min}$. Test-hole information indicates that transmissivity is $6,000 \mathrm{ft}^{2} / \mathrm{d}$. What is the minimum required saturafed thickness? From figure 6 , locate the transmissivity value equal to $6,000 \mathrm{ft}^{2} / \mathrm{d}$ on the horizontal axis. Move vertically up the chart along the $6,000 \mathrm{ft}^{2} / \mathrm{d}$ line to the intersection with the $100 \mathrm{gal} / \mathrm{min}$ diagonal line. Move from this point of intersection horizontally to the saturated thickness axis. The value is 15 feet.

\section{Estimating Transmissivity from Specific Capacity}

Transmissivity can be estimated by specific-capacity data, which are commonly reported by well drillers. A value for specific capacity is obtained by pumping a well at a known constant discharge and measuring the water level in the well after a certain period of time. The recorded drawdown (the static water level minus the pumping water level in the well) is then divided into the pumping rate to obtain the value of specific capacity. Figure 7 can be used to estimate a value of transmissivity for unconfined aquifers from specific-capacity data for pumping periods of 10 minutes, 60 minutes, 8 hours, 24 hours, and 180 days. The estimates assume a well radius of 6 inches and a specific yield of 0.2. The graph in figure 7 also assumes (1) the production well penetrates and is screened through the total saturated thickness of the aquifer, (2) well losses are negligible, and (3) the effective radius of the well has not been affected by drilling and developing the well and is equal to the nominal radius of the well (Walton, 1970). The specific capacity cannot be an exact criterion for obtaining transmissivity because it is rare that all the above criteria are satisfied when obtaining specific-capacity data. In most places these factors adversely affect specific capacity and the actual values of transmissivity estimated from figure 7 will be conservative. An example of the use of figure 7 is:

A 12.0-inch-diameter well is pumped at a constant rate of $150 \mathrm{gal} / \mathrm{min}$. After 1 hour of pumping, the drawdown in the well is 10.0 feet. The specific capacity of the well is calculated to be $150 \mathrm{gal} / \mathrm{min} \div 10 \mathrm{feet}=15(\mathrm{gal} / \mathrm{min}) / \mathrm{ft}$. From figure 7, find the specific-capacity value corresponding to 15 on the horizontal axis. Move vertically along this value to the intersection of the diagonal line for 1 hour of pumping. From this intersection, move horizontally and read the corresponding value of transmissivity of 12,500 (gal/min)/ft. To convert to feet squared per day, divide by

$$
\frac{12,500(\mathrm{gal} / \mathrm{min}) / \mathrm{ft} \times 1,440 \mathrm{~min} / \mathrm{d}}{7.48 \mathrm{gal} / \mathrm{ft}^{3}}=2.4 \times 10^{6} \mathrm{ft}^{2} / \mathrm{d}
$$




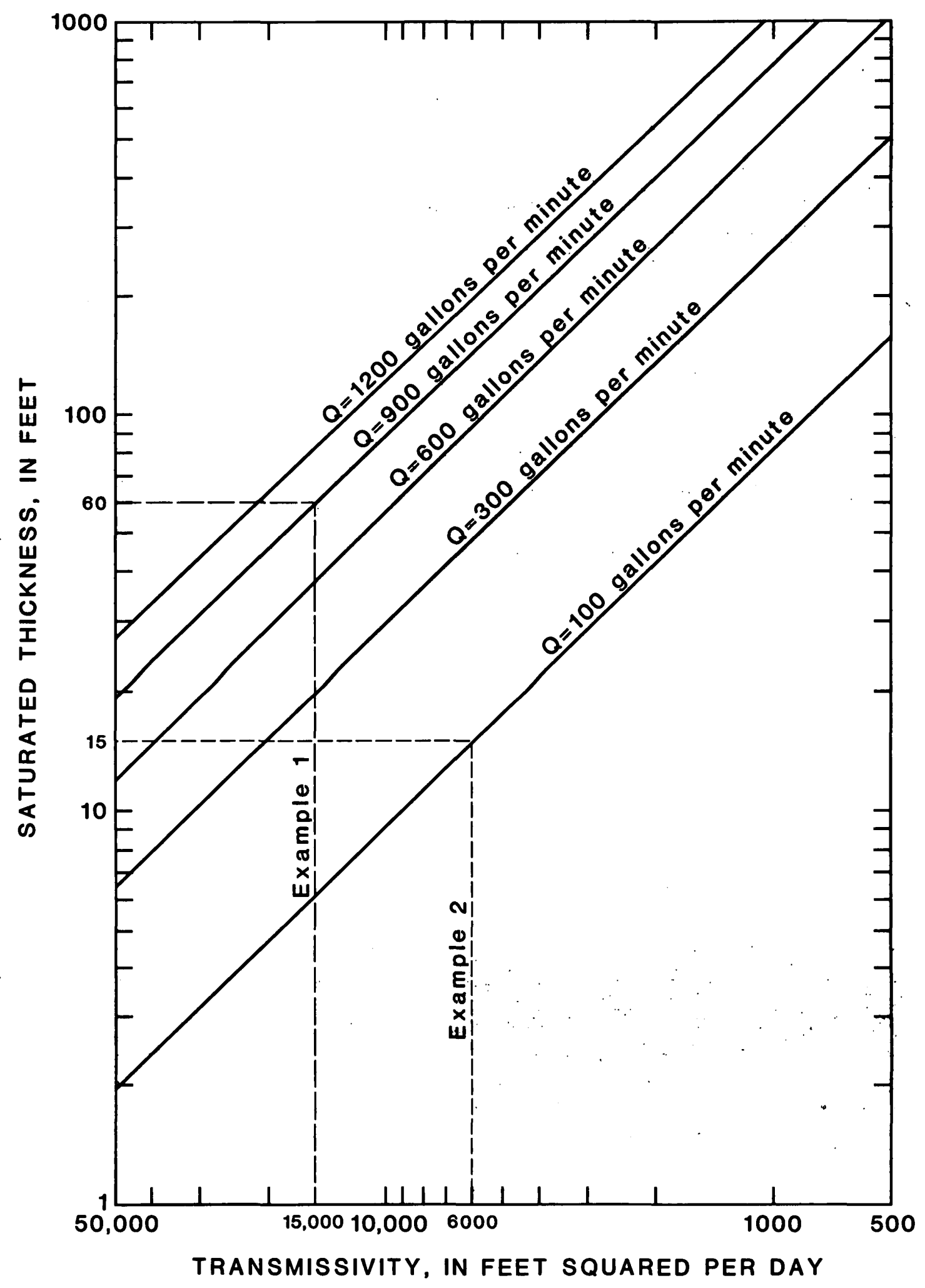

Figure 6.--Estimated maximum yield of wells based on saturated thickness and transmissivity 


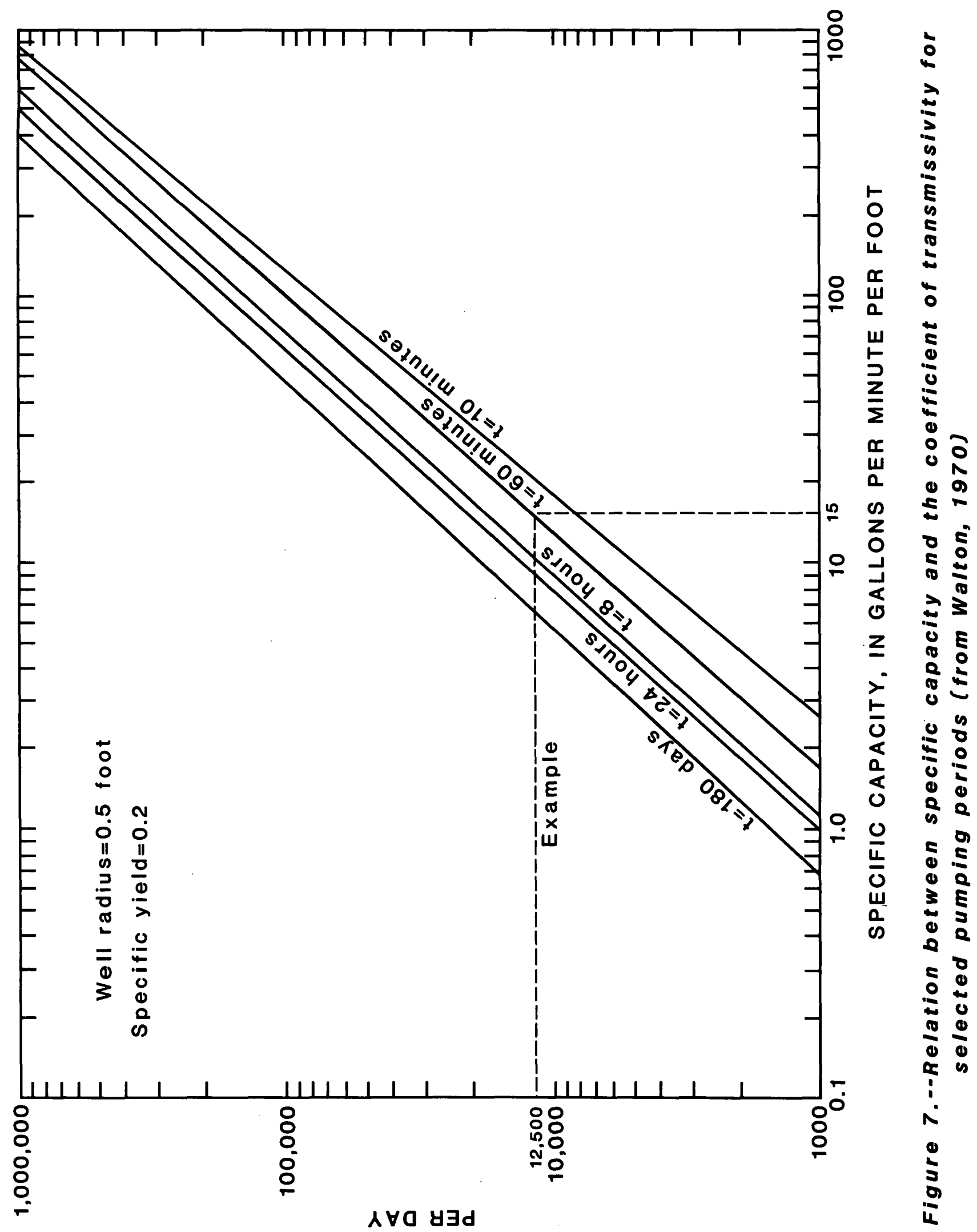

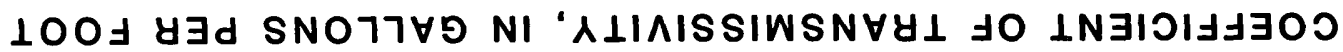




\section{Well Interference}

Closely spaced wells (within a few hundred feet) generally have overlapping cones of influence. The yield of a well decreases as interference from another well increases because of decreases in transmissivity and available drawdown. Well interference can become a critical factor in well yield if it causes drawdown in the well to exceed twothirds of the original saturated thickness.

The location of a well near physical boundaries, such as lakes, streams, or till-sand contact, can also affect drawdown in a well. Figure 8 illustrates several different hydrologic conditions that can affect the drawdown in a well.

Drawdown unadjusted for dewatering, at some distance from a pumping well, may be calculated by the nonequilibrium equation of Theis (1935). Figure 9 summarizes the Theis (1935) nonequilibrium equation for various values of transmissivity, a pumping rate of $500 \mathrm{gal} / \mathrm{min}$ and a storage coefficient of 0.2 . The graph can be used to estimate an unadjusted drawdown at a specific distance from the well and time of pumping. Although the pumping rate used is $500 \mathrm{gal} / \mathrm{min}$, the curves are applicable to other rates because unadjusted drawdown is proportional to the pumping rate. That is, if the rate were 1,000 $\mathrm{gal} / \mathrm{min}$, the unadjusted drawdown at a given distance and time would be twice that indicated in figure 9.

The nonequilibrium method of Theis is not strictly applicable to unconfined aquifers because saturated thickness changes with the water level during pumping. This can be particularly important in the vicinity of a pumped well, where dewatering (decrease in saturated thickness) is greatest.

Adjustment of drawdown for dewatering of the aquifer can be made by use of an equation derived by Jacob (1944), as illustrated in figure 10.

As stated earlier and as shown in figure 8, wells near one another tend to have overlapping cones of influence. At some point, drawdown from a pumping well affected by one or more other pumping wells is equal to the sum of the drawdowns at that point for each of the other pumping wells. Estimates of well interference can be used in choosing optimum well spacing, where multiple wells are needed to obtain adequate irrigation supplies.

The following examples from Larson (1976) illustrate the use of figures 9 and 10 for estimating local effects of pumping and well interference.

Example 1. A well is pumping $1,500 \mathrm{gal} / \mathrm{min}$ from an unconfined (watertable) aquifer where the saturated thickness is 40 feet, the hydraulic conductivity (see table 2) is $500 \mathrm{ft} / \mathrm{d}$, and the storage coefficient is $\mathbf{0 . 2}$. The well is open to the full saturated thickness and is 100 percent efficient.

A. Find the drawdown 1 foot from the center of the well after 5 days of pumping.

1. Transmissivity is $20,000 \mathrm{ft}^{2} / \mathrm{d}(500 \mathrm{ft} / \mathrm{d} \times 40 \mathrm{ft})$.

2. The value of $\mathrm{r}^{2} / \mathrm{t}$ is $0.2 \mathrm{ft}^{2} / \mathrm{d}$ ( $1 \mathrm{ft} \times 1 \mathrm{ft} \div 5$ days). 


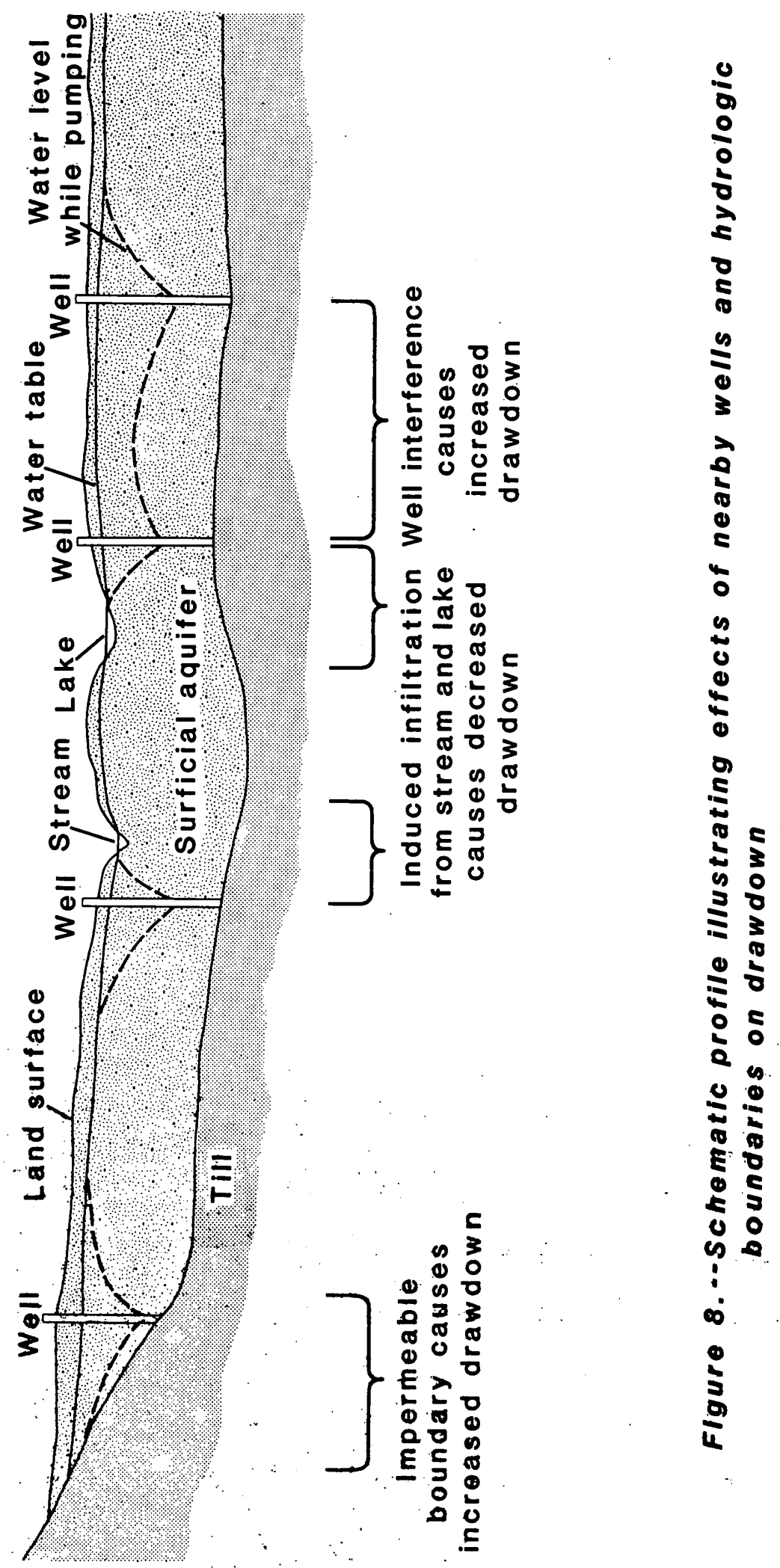




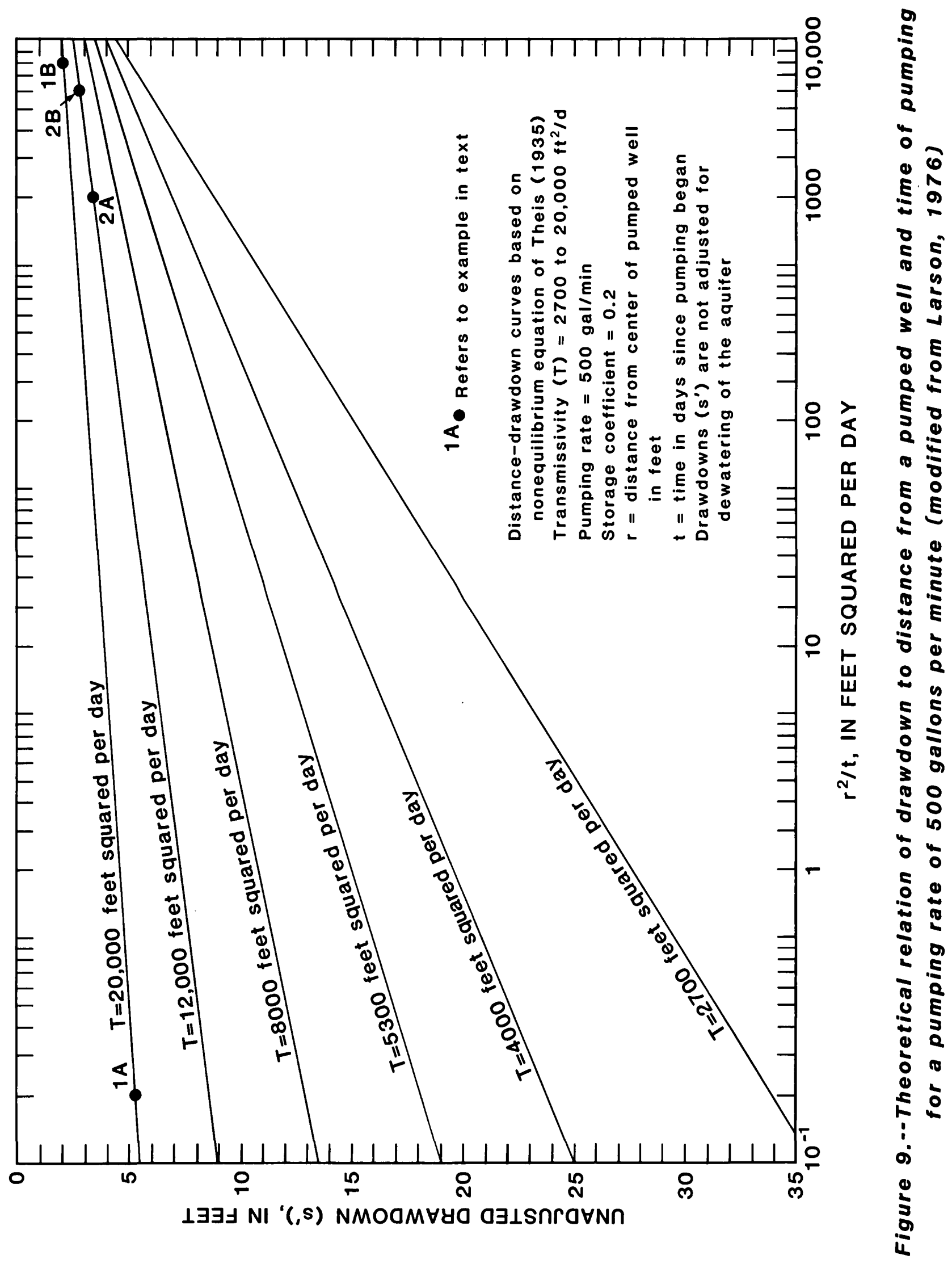




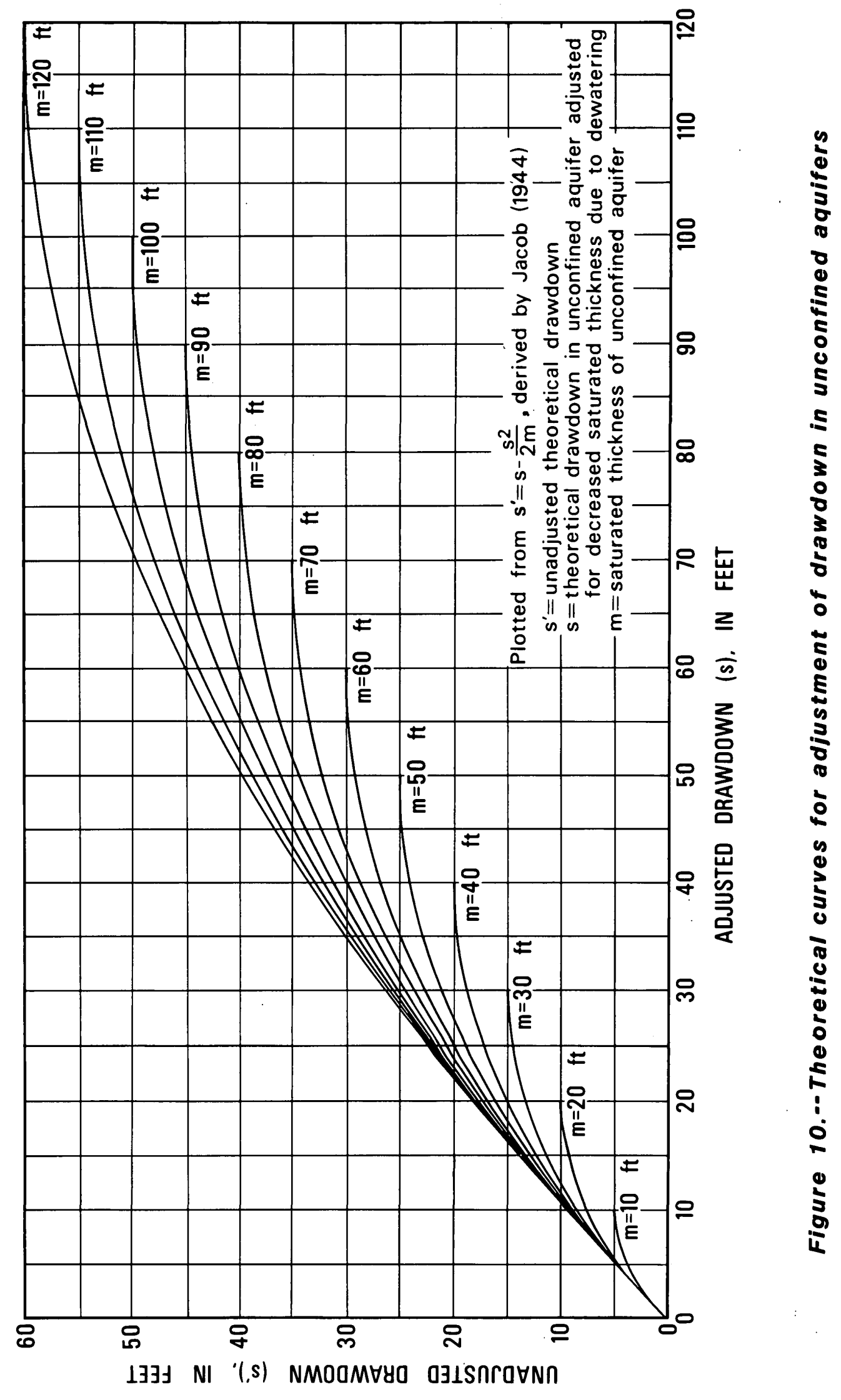


3. From figure 9, the unadjusted drawdown for a well pumping $500 \mathrm{gal} / \mathrm{min}$ is 5.4 feet. For a well pumping 1,500 $\mathrm{gal} / \mathrm{min}$, the unadjusted drawdown is 16.2 feet $(5.4 \mathrm{ft} \mathrm{x}$ 3).

4. From figure 10, the adjusted drawdown is 22.5 feet.

B. Find the drawdown 200 feet from the center of the well after 5 days of pumping.

1. Transmissivity is $20,000 \mathrm{ft}^{2} / \mathrm{d}$.

2. The value of $\mathrm{r}^{2} / \mathrm{t}$ is $8,000 \mathrm{ft}^{2} / \mathrm{d}$ (200 $\mathrm{ft} \times 200 \mathrm{ft} \div 5$ days).

3. From figure 9, the unadjusted drawdown for a well pumping $500 \mathrm{gal} / \mathrm{min}$ is 1.3 feet. For a well pumping 1,500 $\mathrm{gal} / \mathrm{min}$, the unadjusted drawdown'is 3.9 feet ( $1.3 \mathrm{ft} \times 3$ ).

4. From figure 10, the adjusted drawdown is 4.1 feet.

Example 2. Two wells are 200 feet apart. Each pumps $500 \mathrm{gal} / \mathrm{min}$ from an unconfined aquifer where the saturated thickness is 30 feet, transmissivity is $12,000 \mathrm{ft}^{2} / \mathrm{d}$ (hydraulic conductivity of $400 \mathrm{ft} / \mathrm{d}$ ), and storage coefficient is 0.2 The wells are open to the full saturated thickness and are 100 percent efficient.

A. Find the drawdown midway between the two wells after 5 days of pumping.

1. The valye of $r^{2} / t$ for each well at a radius of 100 feet is $2,000 \mathrm{ft}^{2} / \mathrm{d}(100 \mathrm{ft} \times 100 \mathrm{ft} \div 5$ days $)$.

2. From figure 9, the unadjusted drawdown for each well is 2.6 feet.

3. From figure 10, the adjusted drawdown for each well is 2.7 feet.

4. The drawdown midway between the wells is 5.4 feet (2.7 $\mathrm{ft}+2.7 \mathrm{ft}$ ), which is the sum of the drawdowns caused by each well at that point.

B. How far apart should the wells be placed if not more than 4 feet of drawdown is desired midway between them after 5 days of pumping?

1. The adjusted drawdown caused by each well midway between them is intended not to exceed 2 feet $\left(\frac{1}{2} \times 4 \mathrm{ft}\right)$.

2. From figure 10, the unadjusted drawdown caused by each well is 1.9 feet. 
3. From figure $9, \mathrm{r}^{2} / \mathrm{t}$ for an unadjusted drawdown of $\mathbf{1 . 9}$ feet and a transmissivity of $12,000 \mathrm{ft}^{2} / \mathrm{d}$ is about 6,000 $\mathrm{ft}^{2} / \mathrm{d}$. The value of $\mathrm{r}$ is 173 feet if $\mathrm{t}$ is 5 days (square root of the quantity: $6,000 \mathrm{ft}^{2} / \mathrm{d} \times 5$ days $=30,000 \mathrm{ft}^{2}$ ). The distance between the two wells must be at least 346 feet (173 $\mathrm{ft} \times 2$ ) if the drawdown midway between them is not to exceed 4 feet.

These examples illustrate a method of estimating aquifer response in the vicinity of pumped wells. Note, however, that few wells are 100 percent efficient, and drawdowns within wells will be somewhat greater than those predicted by this method.

\section{GROUND-WATER QUALTY}

The chemical quality of water in the surficial aquifer is mainly dependent on the rock type through which it moves and the characteristics of the water it receives as recharge. Table 4 of the companion report (Miller, 1980) lists chemical analyses from 13 wells in the surficial aquifer and one well in a buried aquifer.

Calcium, magnesium, and bicarbonate are the predominant dissolved ions in the ground water. Calcium ranged from 15 to $250 \mathrm{mg} / \mathrm{L}$, with a mean of $90 \mathrm{mg} / \mathrm{L}$; magnesium ranged from 15 to $78 \mathrm{mg} / \mathrm{L}$, with a mean of $25 \mathrm{mg} / \mathrm{L}$; and bicarbonate ranged from 180 to $460 \mathrm{mg} / \mathrm{L}$, with a mean of $320 \mathrm{mg} / \mathrm{L}$. Well-screen incrustations can be associated with these minerals and may pose screen-clogging problems.

Calcium, magnesium, and nitrate are essential plant nutrients. The high concentrations of nitrate in some wells are probably the result of infiltration from barnyards, seepage from domestic septic systems, or infiltration of fertilizers. Water-quality changes resulting from the use of fertilizers may become a problem with more irrigation. Periodic sampling of water quality in wells near irrigated fields can be used to detect possible adverse quality changes in the water.

Dissolved solids and the sodium-adsorption ratio are commonly used to determine the suitability of water for irrigation. The sodium-adsorption ratio is defined as the ratio of sodium to calcium plus magnesium; it enables prediction of the degree to which water tends to enter in to cation exchange in soil. The diagram shown in figure 11 was developed by the U.S. Salinity Laboratory (1954) and is commonly used in evaluating water for irrigation. Specific conductance, in micromhos per centimeter at $25^{\circ} \mathrm{C}$, is an indicator of the dissolved-solids concentration in the water; in the study area, dissolved solids are $\mathbf{0 . 3}$ to 0.7 times the specific conductance. The sodium hazard to soils of water from the surficial aquifer is low, and irrigating with it should pose no problems. Use of water from the only buried aquifer sampled would result in a very high sodium hazard. This water is a sodium bicarbonate type and may not be suitable for irrigating some crops.

Calcium concentration ranged from 15 to $92 \mathrm{mg} / \mathrm{L}$ for all surficial-aquifer wells sampled, except one, where the concentration reached $250 \mathrm{mg} / \mathrm{L}$. This well is on a former Minnesota State Highway Department storage site for road salt. Generally, salt accumulation has not been a problem because the soils are well drained. However, as irrigation increases, salts normally flushed may build up in the ground-water system. Continued water-quality and soil-salinity observation may be warranted if irrigation increases. 


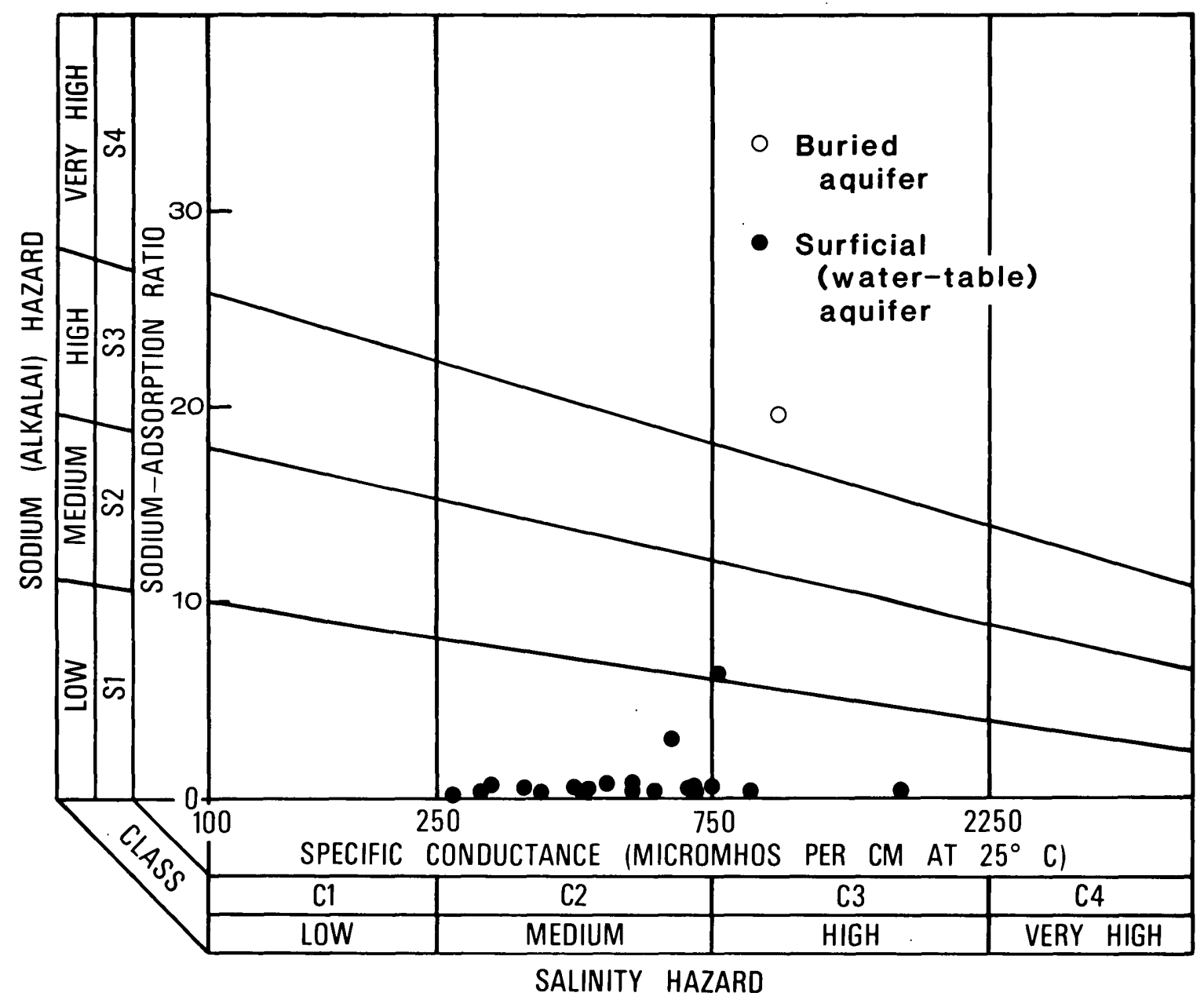

Figure 11.--Suitability of ground water for irrigation in terms of sodium-adsorption ratio and specific conductance (U.S. Salinity Laboratory, 1954) 
Dissolved iron and manganese in water from the surficial aquifer generally exceed the recommended drinking-water standards of 0.3 and $0.05 \mathrm{mg} / \mathrm{L}$, respectively (National Academy of Sciences and National Academy of Engineering, 1973). Use of water containing high concentrations of these elements for irrigation has no apparent harmful effects on plants; however, treatment may be necessary for domestic use.

Boron concentrations in water from wells in the surficial aquifer ranged from 0.01 to $1.1 \mathrm{mg} / \mathrm{L}$ with a mean of $0.4 \mathrm{mg} / \mathrm{L}$. This range is well within acceptable limits for semitolerant plants, such as corn, wheat, barley, oats, potatoes, and sunflowers (U.S. Salinity Laboratory, 1954) that are commonly irrigated in the area. Water from a 400foot deep well tapping a buried aquifer had a boron concentration of $2.5 \mathrm{mg} / \mathrm{L}$. This value is permissible for tolerant plants, such as alfalfa and sugarbeets (U.S. Salinity Laboratory, 1954).

\section{SIMULATION OF SURFICIAL-AQUIFER FLOW SYSTEM}

Three types of hydrologic models were used to examine the surficial-aquifer flow system and the effects of hypothetical pumping on the ground-water-flow system. An analytical model, which utilizes image-well theory (Ferris and others, 1962), was used from Pelican Rapids to the south end of the area to examine the effects of hypothetical pumping along the Pelican River. Numerical models, which solve the governing twodimensional differential equation of flow, were used in the remaining area to simulate hypothetical pumping and the effects on ground-water levels and lakes. For those areas examined by numerical models, a preliminary model was used to determine the sensitivity of various hydrologic-model input parameters and to guide data collection. All three approaches utilized digital computers to aid the corresponding solutions.

\section{Preliminary Flow Model}

Early in the study, preliminary models were constructed for those areas selected for modeling. Areas covered by the preliminary models are similar to those described later in this report. Most of the hydrologic data used in constructing the preliminary models came from drillers' logs of wells and from previous investigations by the U.S. Geological Survey.

Sensitivity analyses were performed on individual preliminary model input parameters, and the results were used as a guide in scheduling additional data collection. The sensitivity-analysis technique involves varying individual preliminary model-input parameters and examining the effects of these changes on the model-computed hydraulic head values. This method was helpful in locating observation wells in both areas modeled. Wells south of Turtle Lake and east and west of Detroit Lakes (pl. 1, map A) were specifically located by this method. A complete description of the use of sensitivity analysis to aid in determining the reliability of model simulation results is contained in the "Sensitivity Analysis" section.

\section{Analytical Model}

Some of the water pumped from wells near streams, rivers, or lakes will be drawn from these water bodies. The percentage of pumped water derived depends on the distance of the well from the water body; the transmissivity of the aquifer, the thickness and hydraulic conductivity of the stream, river, or lake bed, the specific yield of the aquifer, and the duration of pumping. 
Wells in the narrow valley from Pelican Rapids to south of Elizabeth commonly draw some water from the Pelican River. The effects of pumping on flow of the river depend on the number of wells pumping, pumping rates, pumping times, and well locations in relation to one another and to the river.

A hypothetical pumping scheme was devised to examine the effects of pumping on flow of the Pelican River. Hypothetical wells were located from an interpretation of soil maps for Otter Tail County (University of Minnesota, 1969), and from the potential for irrigation as defined by the Soil Conservation Service. Pumping rates for individual wells were calculated by use of the method of images described by Ferris and others (1962). A computer program developed by D. L. Mazzaferro (U.S. Geological Survey, Hartford, Conn. written commun., 1978) was used to speed the mathematical computations. The assumptions listed below were used for computing the pumping rate.

1. The Pelican River was treated as a recharge boundary and is assumed to penetrate the entire saturated thickness of the aquifer.

2. The till-outwash contact was treated as a no-flow boundary.

3. Drawdown in the wells during pumping was not allowed to exceed two-thirds the saturated thickness.

4. Wells were pumped for 30 days with no recharge from precipitation.

5. A value of 0.2 was assumed for specific yield. scheme.

Figure 12 illustrates the location and pumping rate for the hypothetical pumping

A method described by Theis (1941) was applied to each well to estimate the amount of water being diverted from the Pelican River by the hypothetical pumping wells. Using the pumping rates calculated from the image-well theory, and the transmissivity and horizontal distance between the well and the river, the percentage of pumped water drawn from the river can be calculated. Multiplying the percentage by the pumping rate gives the amount being withdrawn from the river. Figure 12 indicates the percentage of water diverted from the Pelican River for each well. The remaining percentage of the water pumped is derived from aquifer storage.

\section{Hypothetical Pumping Effects on the Pelican River, Pelican Rapids to Elizabeth}

The effects of pumping wells near streams are most critical when streamflow is low. During low flow, nearly all the water in the stream is from ground-water discharge. Table 3 shows the magnitude and frequency of annual low flows computed for the Pelican River at a continuous-record gaging station 3 miles south of Elizabeth. The table, which can be used to examine the probability of sustained periods of low streamflow, indicates that a discharge of less than $3.76 \mathrm{ft}^{3} / \mathrm{s}$ for 30 consecutive days occurs about once in 5 years. 


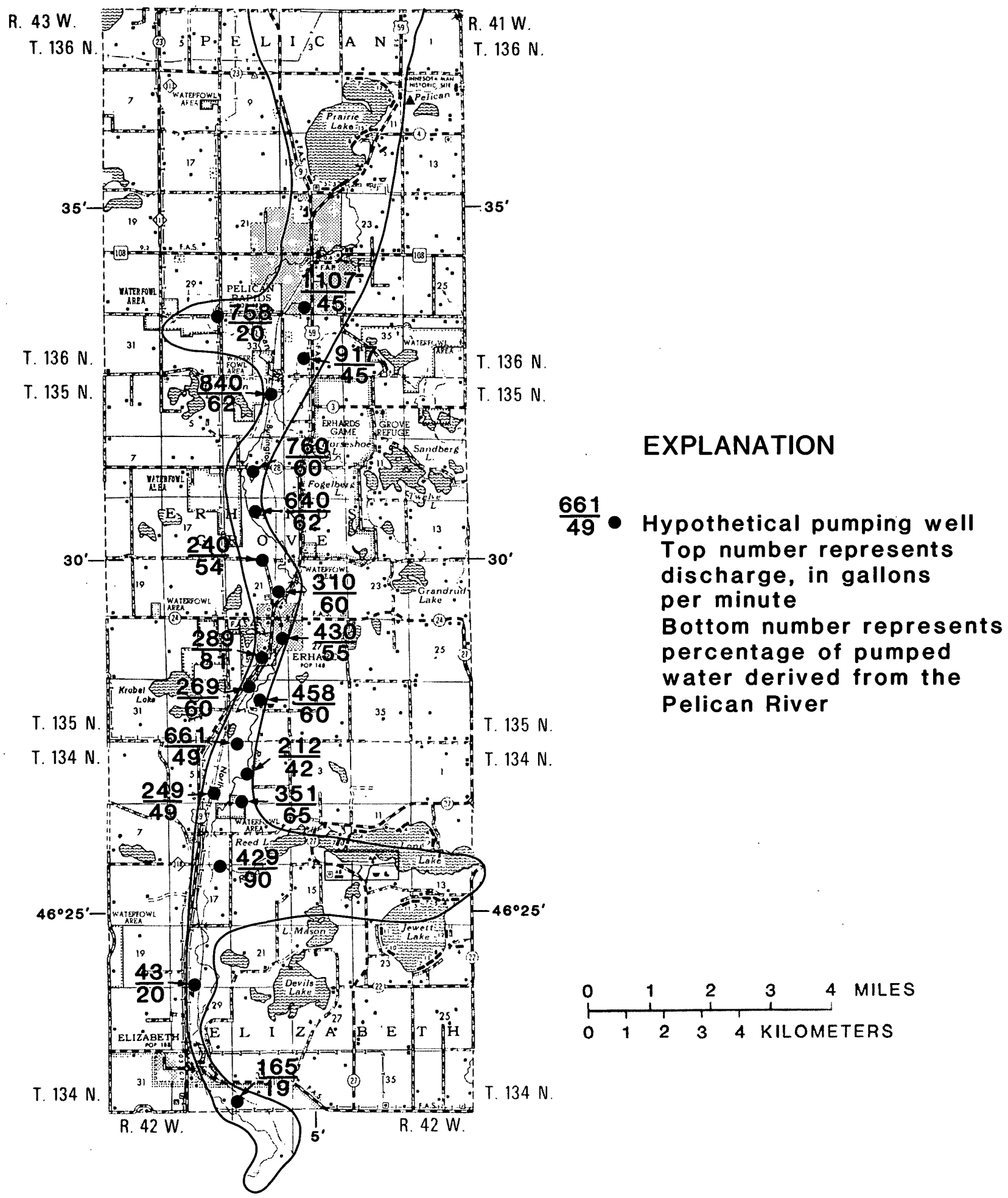

Figure 12.--Location, discharge, and percentage of water derived from pumping wells along the Pelican River 
Table 3.-Magnitude and frequency of annual low flows for the

Pelican River near Pergus Falls, station number 05040500

(From Lindskov, 1977)

\begin{tabular}{|c|c|c|c|c|c|c|}
\hline \multirow{2}{*}{$\begin{array}{c}\text { Period } \\
\text { (consecutive } \\
\text { days) }\end{array}$} & \multicolumn{6}{|c|}{$\begin{array}{l}\text { Annual low flow, in cubic feet per second, } \\
\text { for indicated recurrence interval, in years }\end{array}$} \\
\hline & 2 & 5 & 10 & 20 & 50 & 100 \\
\hline 1 & 12.5 & 2.22 & .23 & 0 & 0 & 0 \\
\hline 7 & 15.3 & 3.23 & .37 & 0 & 0 & 0 \\
\hline 14 & 15.7 & 3.26 & .42 & 0 & 0 & 0 \\
\hline 30 & 16.6 & 3.76 & .52 & 0 & 0 & 0 \\
\hline 60 & 19.2 & 4.35 & 1.03 & 0 & 0 & 0 \\
\hline 90 & 21.6 & 4.50 & 1.28 & .36 & .07 & .02 \\
\hline 120 & 24.2 & 7.97 & 3.94 & 2.05 & .92 & .51 \\
\hline 183 & 31.1 & 12.6 & 7.25 & 4.37 & 2.35 & 1.51 \\
\hline 365 & 77.2 & 48.8 & 36.4 & 27.8 & 19.8 & 15.5 \\
\hline
\end{tabular}

The amount and location of ground-water discharge to the Pelican River was determined from a base-flow survey made October 20-21, 1980. By measuring streamflow at selected points from Pelican Rapids south to Elizabeth, the areas of greatest groundwater discharge along the river were identified. Ground-water discharge to the Pelican River and the amount of pumpage derived from the Pelican River for the hypothetical pumping scheme is summarized on figure 13.

The estimated effects of hypothetical pumping on streamflow in any reach of the Pelican River can be estimated by summing the total pumping-well withdrawal effect in cubic feet per second upstream from the point in question. An example of this is:

What effect will the hypothetical pumping well scheme have on flow of the Pelicen River measured at Erhard?

1. From figure 13 sum the total well withdrawals upstream from . Erhard $(0.34+1.11+0.92+1.16+0.89+1.02+0.41+0.29)=6.14 \mathrm{ft}^{3} / \mathrm{s}$ loss of flow in the Pelican River.

If this pumping had taken place during base flow (October 20-21, 1980), the total flow in the Pelican River would be the total sţreamflow at Erhard minus the loss due to pumping $\left(8.60 \mathrm{ft}^{3} / \mathrm{s}\right.$ minus $\left.6.14 \mathrm{ft}^{3} / \mathrm{s}\right)$, or $2.46 \mathrm{ft}^{3} / \mathrm{s}$ flow in the Pelican River.

It is emphasized again that the wells used in the above example are hypothetical. Exoh new exoposed well would need to be examined on an individural basis. The example doos illustrate (1) the methods available to examine the effects of indivichal and cumulative woll pumpage an streamflow, and (2) that pumping in this part of the area can dectease streamnow in the Pelican River. 


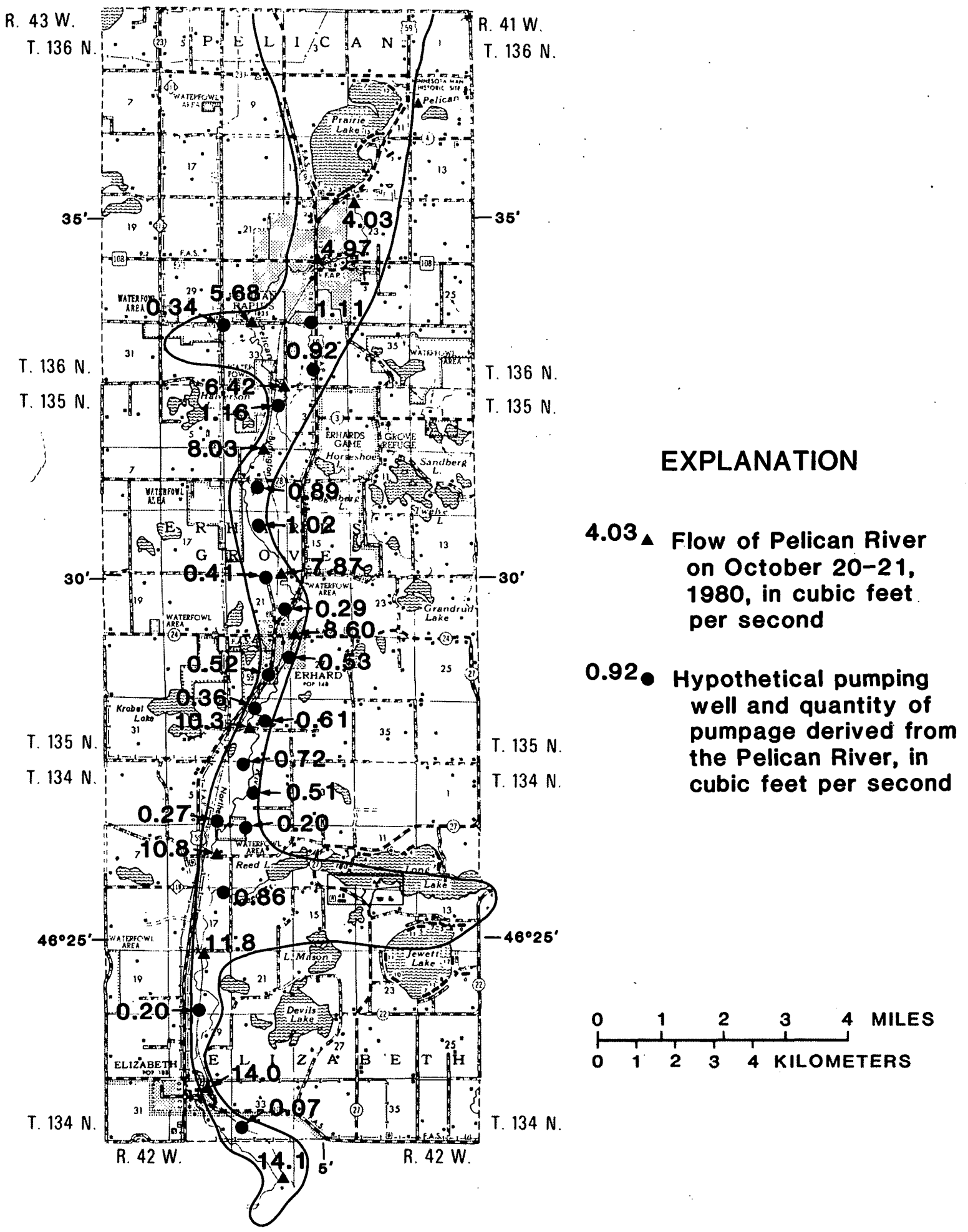

Figure 13.--Flow of the Pelican River and quantity of hypothetical pumpage derived from streamflow 


\section{Numerical Model}

The numerical model developed by Trescott and others (1976) was used to simulate the surficial-aquifer system and to evaluate the effects of hypothetical pumping on lakes. The model represents the area not covered by the analytical method; it was used to simulate ground-water flow under equilibrium (steady-state) conditions and to estimate long-term water-level changes as a result of hypothetical pumping. More importantly, the effects of aquifer boundaries and evapotranspiration from streams, lakes, and ground-water can be incorporated in the model simulation.

The model does not simulate the ground-water-flow system in every detail and, therefore, can only be considered an approximation. However, it is a valuable tool for estimating long-term regional effects of ground-water withdrawals. Local, short-term responses can also be estimated by a model of this type, but the analytical techniques previously discussed are easier to apply and give adequate results.

\section{Description of model}

The model program developed by Trescott and others (1976) uses finite-difference methods to obtain solutions to the partial-differential equation of ground-water flow in two dimensions as given below:

$$
\frac{\partial}{\partial x}\left(K_{x x} b \frac{h}{x}\right)+\frac{\partial}{\partial y}\left(K_{y y} b \frac{h}{y}\right)=S_{y} \frac{\partial h}{\partial t}+W(x, y, t)
$$

where

$K_{x a x}, K_{y y}$ are the principal components of the hydraulic conductivity tensor

$S_{y}$ is the specific yield of the aquifer (dimensionless),

$b$ is the saturated thickness of the aquifer (L),

$h$ is the hydraulic head ( $\mathrm{L})$,

$t$ is time $(t)$, and

$W$ is a source/sink term $\left(\mathrm{L}^{3^{3}}{ }^{-1}\right)$.

This equation assumes that the coordinate axes are alined with the principal components of the hydraulic conductivity tensor. A complete description and theoretical development of the above equation and the strongly implicit procedure used to solve the resulting set of simultaneous equations can be found in Trescott and others (1976). A modification for computation of ground-water flow past a specific model grid point was incorporated into the model program to examine ground-water flow simulated into and out of lakes.

A finite-difference grid is used to divide the model area into rectangular blocks. Aquifer properties and characteristics are specified at the center (or node) of each grid block. The matrix of nodes represents the size and characteristics of the real aquifer, and the solution of the above described equation results in a definition of the areal 
distribution of hydraulic head in the aquifer. These model-computed heads can then be compared against water levels measured in wells, and the model simulation can be evaluated for accuracy.

Data inputs at each node consist of (1) hydraulic conductivity, (2) estimated hydraulic head, (3) aquifer-base altitude, (4) dimensions of each grid block, and (5) hydraulic stresses such as ground-water-recharge rate, pumping, and evapotranspiration. Transmissivity is computed by the model as the product of hydraulic conductivity and saturated thickness, which is also computed by the model as the difference in altitude between the hydraulic head and the base of the aquifer. This allows the model to account for changes in transmissivity as water levels respond to pumping or recharging wells. Because only equilibrium (or steady-state) simulations were made, the specific yield of the aquifer was not required.

Hydrologic boundaries are specified by selecting one of the four possible boundary conditions: (1) no flow across the boundary, (2) constant flux across the boundary, (3) constant hydraulic head at the boundary, or (4) hydraulic-head-dependent leakage across the boundary. By specifying a no-flow boundary, the model allows no ground-water flow across the boundary in the simulation. A constant-flux boundary specifies a constant rate of flow across the boundary that does not change regardless of any stress applied to the model during the simulation. Constant-head boundary conditions specify that the hydraulic head is not calculated by the model at the boundary. Instead, the head is set at some predetermined level and is not changed during the simulation. Ground-water flow across constant-head boundaries is related to transmissivity and the computed hydraulic gradient near the boundary. By specifying head-dependent boundary conditions, the rate of ground-water flow across the boundary is calculated by the model in relation to the transmissivity and the difference between a model-computed head at the boundary and a fixed head specified in the model. A leakage coefficient is also used in the model to control the amount of ground water moving across this type of boundary. The rate of groundwater flow across head-dependent boundaries varies throughout the model simulation, as it is directly related to a changing hydraulic head at the boundary. Where head-dependent boundary conditions are used to simulate lakes, the fixed hydraulic head represents the lake level, and the leakage coefficient is the hydraulic conductivity of the lake bottom divided by the thickness of the lake bottom. For simulation of lateral boundaries, the fixed head is a known water level outside the modeled area, and the leakage coefficient is the hydraulic conductivity between the known head and the boundary divided by this distance.

Two models were constructed to simulate steady-state ground-water flow nor th of Pelican Rapids. For reference, they will be referred to as the Scambler model and the Detroit Lakes model. The boundaries of the model areas are shown on plate 2. Note that, although these models share a common boundary (Pelican Lake), they are entirely independent for simulation purposes.

\section{Scambler model}

A 1,600 node ( $32 \times 50)$ grid was used to model the Scambler area. Each grid block is represented by a square 1,600 feet on a side. The grid design and orientation were based on the shape and areal extent of the aquifer, the amount of hydrologic data available, and the general direction of ground-water flow, which is parallel to the major axis of the grid blocks. 
Maps were constructed from available well drillers' logs and the logs of test holes described in Miller (1980) showing the configuration of the water table and the base of the aquifer (top of the underlying till) and the areal distribution of hydraulic conductivity. Land-surface altitude was estimated from 7.5-minute topographic maps.

Four types of boundary conditions were simulated. Constant-head boundaries were used to simulate major lakes on the boundary, such as Middle Cormorant Lake, Pelican Lake, and Lake Lizzie that are on the eastern boundary. Constant heads were used because the area of the lakes is so large that changes in water level in the aquifer will have little effect on lake levels or volumes of water in storage. The lakes also receive large amounts of water from outside the model boundaries. Hydraulic head values for the constant-head boundaries were obtained from observation wells at or near the boundary or from normal lake levels indicated on topographic maps.

A head-dependent-flux condition was used along the southern boundary of the model to simulate ground-water flow out of the modeled area. Head-dependent-flux conditions were chosen because the rate of ground-water flow depends on the hydraulic head at the boundary and because stresses to be simulated in the model may cause a change in head computed at the boundary. The initial fixed head for this head-dependent-flux boundary was obtained from an observation well 1,000 feet south of the boundary. The leakage coefficient was calculated by dividing the average horizontal hydraulic conductivity by the horizontal distance between the observation well and the model boundary.

The remainder of the model boundary was treated as a no-flow boundary. As described earlier, the total contribution of ground water to the surficial-aquifer system across the outwash-till contact is extremely small, and the contact can be treated as a no-flow boundary.

Major lakes totally within the model area were simulated by specifying the head in each and allowing leakage to occur between the lake and the aquifer based on the difference in head. If the head in the aquifer was higher than the head in the lake, water would flow from the aquifer into the lake. If the lake head was higher than aquifer head, then the water would flow from the lake into the aquifer. This same approach was used successfully by Larson and others (1975) in examining the lake-ground-water interaction around Lake Sallie (located in the Detroit Lakes model). The lake-bottom leakage coefficient is calculated by dividing the vertical hydraulic conductivity by the thickness of the lake-bottom sediments for the individual lakes. Larson and others (1975) obtained reasonable results for a similar model simylation by using a thickness of 0.01 foot and a vertical hydraulic conductivity of $2.3 \times 10^{-8} \mathrm{ft} / \mathrm{s}$.

Values of areal recharge for both models were obtained by analysis of hydrographs for observation wells within the appropriate area (fig. 2). Values of areal recharge for the Scambler model area ranged from 3.9 to 4.1 inches per year. A uniform recharge rate of 4.0 inches per year was used for steady-state model calibration.

Evapotranspiration in the Scambler model area was calculated (Thornthwaite, 1939) to be 20.8 inches per year during 1979-80. This value is in close agreement with the 22.4 inches per year calculated by Winter and others (1969). The calculation of 20.8 inches per year was used for steady-state model calibration. This value of evapotranspiration decreases linearly in response to a lowering water table. When the water table is at land surface, 20.8 inches per year is simulated. When the water table is at depths of 5 feet or more below land surface, no evapotranspiration is simulated. 


\section{Detroit Lakes model}

The grid for the Detroit Lakes model has 2,205 nodes (49 $\times 45)$. The grid blocks have the same dimensions as those in the Scambler model, 1,600 x 1,600 feet. Grid design and orientation were based on the shape and areal extent of the aquifer, the amount of hydrologic data available, and the general direction of ground-water flow. The major axis of this grid is either parallel or perpendicular to the general direction of groundwater flow.

Maps showing the configuration of the water table and base of the aquifer and the areal distribution of hydraulic conductivity were constructed similarly to those for the Scambler model. Land-surface altitude was estimated from appropriate 7.5-minute topographic maps.

The four types of boundary conditions described for the Scambler model were also used in the Detroit Lakes model. Constant-head boundaries were used to simulate Pelican and Middle Cormorant Lakes because of the lakes' large size and interaction with ground water. Hydraulic-head values were obtained from observation wells at or near the boundary, or from 7.5-minute topographic maps. Head-dependent flux conditions were used to simulate ground-water inflow along the northern boundary, part of the eastern boundary near Detroit Lake, and part of the western boundary near Lake Sallie. This was done so that computed ground-water flow across the boundaries could vary with changing water levels near the boundaries. The remaining areal boundaries were treated as no-flow because they are outwash-till contacts with no significant ground-water flow across them.

Floyd Lake, Detroit Lake, Lake Melissa, and Lake Sallie were modeled in the same manner as the interior lakes in the Scambler model. The thickness and vertical hydraulic conductivity of the lake-bottom sediments were 0.01 foot and $2.7 \times 10^{-8} \mathrm{ft} / \mathrm{s}$, respectively.

Values of recharge were estimated as previously described (fig. 3). Areal recharge ranged from 3.5 to 4.8 inches per year. A value of 4.2 inches per year was used for the steady-state calibration of the model. Evapotranspiration was calculated as for the Scambler model, with a linear reduction in rate from 20.8 inches per year at land surface to 0 inches per year at depths of 5 feet and greater below land surface.

\section{Model calibration}

From the data and boundary conditions previously described, each model was calibrated independently for equilibrium conditions. Water-table maps generated by each model, along with computed values of ground-water discharge for Lake Sallie in the Detroit Lakes model were compared to the average water table (pl. 1) and to lake budgets determined for Lake Sallie by Mann and McBride (1972).

Small adjustments were made in values of hydraulic conductivity until water levels and ground-water discharge were acceptably simulated. Adjustments in hydraulic conductivity were made only at or near observation wells for which water-level information was available. Before the adjustments, nearly all model-computed hydraulic heads were within 2.5 feet of measured water levels. Exceptions to this were near lateral boundaries directly east and west of Detroit Lakes in the Detroit Lakes model and the northern section of the Scambler model. Computed heads for these areas were generally 5 to 7 feet 
higher than measured water levels. The value of hydraulic conductivity in these areas was increased by no more than 25 percent of the original value to lower the value of computed head to within 2.5 feet of measured water levels. Values of ground-water discharge to Lake Sallie were adjusted by increasing or decreasing the value of vertical hydraulic conductivity of lake-bottom sediments. A value of $3.1 \times 10^{-7} \mathrm{ft} / \mathrm{s}$ was used, which gives ground-water discharge results close to those of the flow-net analysis by Mann and Mcbride (1972). This same value for lake-bottom vertical hydraulicconductivity was used for Floyd Lake, Detroit Lake, and Lake Melissa in the Detroit Lakes model. Flow rates at equilibrium for the various components of the modelcalculated water budget are shown in table 4 for each model area.

Table 4.-Model-calculated water budget

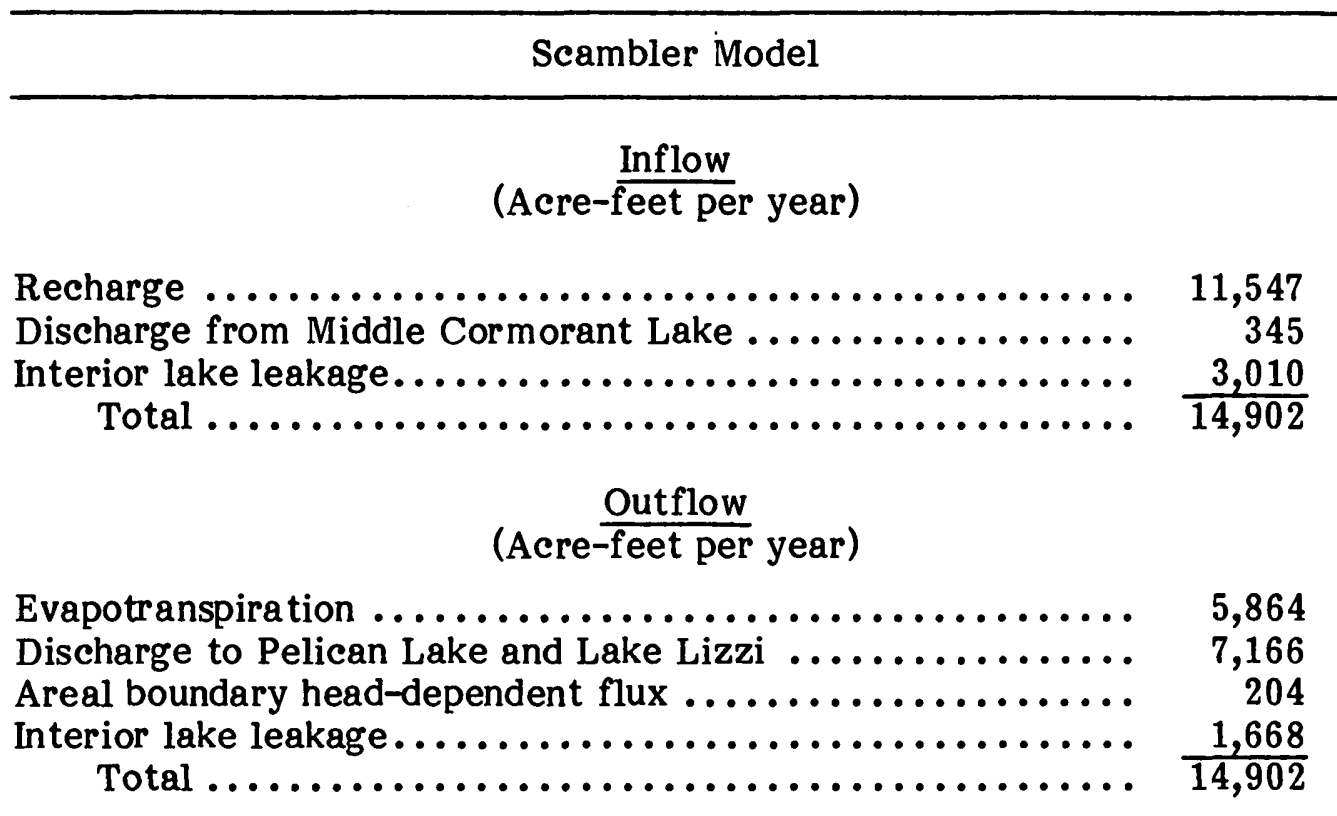

Detroit Lakes Model

\section{Inflow \\ (Acre-feet per year)}

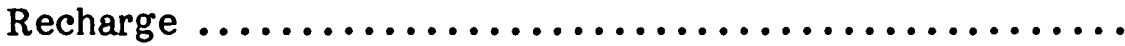

Areal boundary head-dependent flux ................

Discharge from Big Cor morant Lake ................

Interior lake leakage $\ldots \ldots \ldots \ldots \ldots \ldots \ldots \ldots \ldots \ldots \ldots$

Total

16,865

Outflow

(Acre-feet per year)

Evapotranspiration ........................ 15,127

Discharge to Pelican Lake .................... 3,851

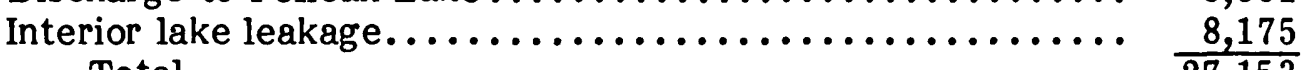

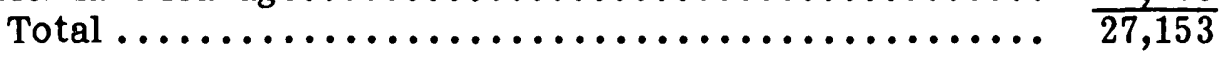




\section{Analysis of hypothetical pumping}

The calibrated steady-state models were used to examine the effects of groundwater withdrawals on ground-water and lake levels. However, the scale of the models is such that the effects of individual wells cannot be evaluated. The most detailed waterlevel changes calculated by the model represent average changes over the area of a single grid block, or approximately 60 acres.

Withdrawals from the surficial-aquifer system will change the recharge-discharge relationship, and water levels will decline in response to the amount and location of withdrawal. This, in turn, will affect the rate of evapotranspiration, the amount of ground water interacting with lakes, and the amount of water flowing across area boundaries.

The effects of ground-water withdrawals on both the Scambler and Detroit Lakes model areas were independently studied with steady-state (or equilibrium) model simulations. Each simulation included a hypothetical pumping scheme, developed similarly to that used for the analytical model, and either normal or reduced recharge. Even though the models are independent of each other, they share a common boundary, Pelican Lake, which is simulated in both models as constant head. This should not pose a problem in individual model analyses because the lake receives ample inflow from surface-water and ground-water sources outside the model areas. Pumping and recharge rates for the model simulations are described below:

1. Hypothetical pumping development, normal recharge. A hypothetical pumping scheme was developed from the potential pumping rates shown on plate 1 . Plate 2 indicates the location of the hypothetical pumping wells, rate of withdrawal, and resulting water-level declines. The rate of withdrawal from each well for the model simulation is representative of the pumping rate shown on plate 2, map $B$. As the model simulates this rate continuously, the actual value used in the model was divided by 4 . This was done to simulate a rate equal to 3 months of continuous pumping.

2. Hypothetical pumping development, reduced recharge. Hypothetical pumping was the same as in model-simulation 1 except that half the average annual recharge was simulated. Plate 2 indicates locations and representative pumping rates for the hypothetical wells and the resulting water-level declines. The model pumping rates were computed similarly to simulation 1.

Plate 2 shows that water-level declines are generally largest in areas of greatest pumpage farthest from possible sources of induced recharge (lakes). It is not possible to predict the exact lowering of lake levels due to pumping without considering the storage of the lakes and the ground-water system and the actual duration of the conditions simulated. Plate 2 illustrates that the regional lowering of water levels due to the hypothetical pumping scheme for reduced recharge conditions could lower some lake levels from 2 to 10 feet, at equilibrium.

\section{Scambler model}

For both steady-state model simulations, water-table declines are largest in the northern half of the area. Under normal recharge conditions, drawdowns approximated 8 feet near Turtle Lake and 4 feet near Lake Ida. Drawdowns of 2 feet were indicated near Tamarac Lake. Little drawdown was calculated for the southern part of the area near Prairie Lake. 
For half the normal recharge, calculated drawdowns in model areas more than doubled. An especially critical area was indicated from Lake Ida north, where drawdowns exceeded 10 feet in most places and reached a maximum of 25 feet nor th of Turtle Lake. Drawdowns for the remainder of the area were near 5 feet.

It is emphasized that the model-computed drawdowns were produced by simulation of hypothetical wells pumping the theoretical optimum yields shown in plate 1D. The wells were pumped at a constant rate and represent long-term continuous pumpage. The drawdowns indicated the effects of well interference and problems that must be anticipated when siting pumping wells. Even if an area has the potential for large-capacity wells, such as the northern half of the Scambler model area, an evaluation of the number and location of wells is critical when estimating the amount of potential drawdown for a specific area.

The effects of drawdown on lake levels are difficult to quantify with the twodimensional ground-water-flow modeling techniques described here, because outside sources of surface water are not taken into account by the model. Consequently, the calculated drawdowns around the lakes show a maximum potential lake drawdown for the conditions simulated.

Another way to study the effects of hypothetical pumping on the ground-water system and lakes is to examine the model-computed ground-water sources and discharges. Table 5 describes the sourees and discharges of ground water in the Scambler model for the calibrated model and the hypothetical pumping simulations. Actual volumes of water calculated by the model have been converted to percentages of either total sources or total discharges for comparison purposes. Under current conditions, recharge from precipitation is the major source of ground water for the Scambler model, with lesser percentages of water coming as leakage from Lake Ida and Tamarac Lake. Discharges from the model area are primarily through nearly equal percentages of evapotranspiration and flow to Pelican Lake. Smaller discharges are flow to Prairie Lake, Middle Cormorant Lake, Lake Lizzi, and the southern head-dependent flux boundary.

Under hypothetical pumping conditions with normal areal recharge, Prairie Lake and Middle Cormorant Lake change from discharge areas to source areas of ground water. This is due to the general water-level declines around these lakes. Discharges from the aquifer are split approximately equally between evapotranspiration, flow to Pelican Lake, and hypothetical pumpage, with lesser amounts leaving as flow to Lake Lizzi and across the southern head-dependent-flux model boundary.

For hypothetical pumping under reduced areal recharge conditions, less than half of the total source of ground water is from areal recharge. Instead, leakage from Lake Ida and Prairie Lake constitute the major sources of water. Tamarac and Middle Cormorant Lakes also supply ground water through increased induced leakage. The major discharge from the system is through hypothetical pumping. Discharge to Pelican Lake and evapotranspiration constitute smaller percentages of total discharge. Small amounts of ground water still discharge to Lake Lizzi and across the southern head-dependent-flux model boundary.

Model results indicate that pumping under different conditions of areal recharge in the Scambler model area will appreciably affect the source and discharge characteristics of the surficial aquifer. In some cases, lakes that normally act as discharge areas for ground water may become source areas. This will be due to the lowering of the regional 
water table by increased pumping and reduced recharge. A decrease in the amount of ground-water flow into a lake and an increase in the amount of leakage from a lake will tend to lower lake levels.

Table 5.-Percentage of total ground-water sources and discharges for steady-state simulations using the Scambler numerical model

\begin{tabular}{|c|c|c|c|}
\hline & Calibrated model & $\begin{array}{l}\text { Pumping } \\
\text { simulation } 1\end{array}$ & $\begin{array}{l}\text { Pumping } \\
\text { simulation } 2\end{array}$ \\
\hline Parameter & $\begin{array}{c}\text { No pumping stress, } \\
\text { areal recharge = } \\
4.0 \mathrm{in} / \mathrm{yr}\end{array}$ & $\begin{array}{l}\text { Hypothetical } \\
\text { pumping stress, } \\
\text { areal recharge = } \\
4.0 \mathrm{in} / \mathrm{yr}\end{array}$ & $\begin{array}{l}\text { Hypothetical } \\
\text { pumping stress, } \\
\text { areal recharge = } \\
2.0 \mathrm{in} / \mathrm{yr}\end{array}$ \\
\hline
\end{tabular}

Sources (percent of total)

\begin{tabular}{lcrr}
\hline & 87.93 & 77.72 & 45.46 \\
Areal recharge & 11.27 & 19.49 & 31.40 \\
Lake Ida & - & .86 & 11.78 \\
Prairie Lake & -80 & 1.53 & 6.39 \\
Tamarac Lake & - & .39 & 4.95 \\
$\begin{array}{l}\text { Middle Cor morant } \\
\text { Total }\end{array}$ & 100 & 100 & 100 \\
\hline
\end{tabular}

Discharges (percent of total)

\begin{tabular}{lccc}
\hline Evapotranspiration & 45.51 & 32.25 & 28.11 \\
Pumpage & - & 31.14 & 36.10 \\
Southern head-dependent & \multicolumn{1}{c}{} & 1.61 \\
$\quad$ flux boundary & 1.58 & 1.36 & - \\
Prairie Lake & 1.19 & - & 31.69 \\
Middle Cormorant Lake & 0.58 & 31.49 & 2.48 \\
Pelican Lake & 47.99 & 3.76 & 100 \\
Lake Lizzi & 3.15 & 100 & \\
$\quad$ Total & 100 & & \\
\hline
\end{tabular}

\section{Detroit Lakes model}

Drawdowns calculated for the Detroit Lakes model area are not as great as those for the Scambler model area. This is primarily because there are more large lakes that supply water to the ground-water system by induced recharge near potentially high pumping areas in the Detroit Lakes model (pl. 1, map D). Drawdowns under normal recharge conditions ( 6 feet) are greatest nor th of Pelican Lake (pl. 2, map C). Drawdown is 2 feet in a small area north of Detroit Lake. Dividing the recharge in half generally doubles the drawdown for this area. The maximum drawdown for the hypothetical pumping with half the normal recharge (pl. 2, map D) is $10 \mathrm{feet}$, which occurs from Lake 
Eunice nor th to the model boundary. Drawdown of 5 feet is found just north of Pelican Lake and north of Detroit Lake west to the model boundary. Drawdowns in these areas are the result of high rates of simulated pumping similar to those described for the northern part of the Scambler model. Again, even though an area may have the potential for large well yields, critical evaluation of the siting of the well in relationship to other wells is important when estimating potential maximum drawdowns.

The drawdowns discussed result from simulated pumping of hypothetical wells located by use of plate $1 \mathrm{D}$, which shows theoretical optimum yields to wells in surficial aquifers. The wells are pumped at a constant rate for long periods. The drawdowns include the effects of well interference, which must be anticipated when siting pumping wells.

The same problems that are faced when using the Scambler model for predicting lake-level declines from the hypothetical pumping wells are also true for the Detroit Lakes model. Sources of surface water to the lakes from outside the model area affect actual lake levels; the computed drawdowns around lakes represent a potential maximum lowering of lake levels.

Table 6 illustrates the effects of pumping on lakes in the Detroit Lakes model. The two hypothetical simulations previously described are compared to the calibrated model. Rates of flow calculated by the model have again been converted to percentages of either total sources or total discharges for comparison. An examination of table 6 indicates results similar to those obtained for the Scambler model.

For the calibrated model, areal recharge is the major source of ground water. The remaining sources are approximately equally distributed between leakage from Floyd and Big Cormorant Lakes and flow from constant-head and head-dependent flux boundaries. Discharges are mainly through evapotranspiration and flow to Pelican Lake. Flow to Detroit Lake, Lake Sallie, and Lake Melissa constitute the remaining discharge.

For the simulation with hypothetical pumpage and normal areal recharge, areal recharge is still the major source of ground water. The other sources, leakage from Floyd Lake, flow from Big Cormorant Lake, and constant-head boundaries are greater than in the previous simulation. Evapotranspiration constitutes over half the discharge from the system, and discharge to Detroit Lake, Lake Sallie, Lake Melissa, and Pelican Lake decreases.

In the simulation of hypothetical pumpage with half normal areal recharge, the general ground-water gradient is reversed, and water is induced from Detroit Lake and Lake Melissa into the aquifer. Areal recharge supplies less than half of the inflow to the ground-water system, and leakage from Floyd and Big Cormorant Lakes and flow across the constant-head and flux boundaries increase. Discharge from the ground-water system consists almost entirely of evapotranspiration and hypothetical pumping. Smaller amounts of ground water discharge to Lake Sallie and Pelican Lake.

To summarize, for both the Scambler and Detroit Lakes model areas, model results indicate that areal recharge and evapotranspiration are at present the major source and major discharge of ground water, respectively. These two parameters are also dominant for both both hypothetical pumping simulations. Although Detroit Lake and Lake Melissa are discharge areas for ground water under normal conditions, the lakes are source areas for ground water under conditions of hypothetical pumping during periods of reduced 
areal recharge. In general, the model simulations indicate that the lowering of ground water by pumping wells can affect lake levels in the study area. The models also indicate that the lowering of water levels is compounded in some areas during long-term droughts.

Table 6.-Percentages of total ground-water sources and discharges for steady-state simulations for the Detroit Lakes numerical model

\begin{tabular}{|c|c|c|c|}
\hline & Calibrated model & $\begin{array}{l}\text { Pumping } \\
\text { simulation } 1\end{array}$ & $\begin{array}{l}\text { Pumping } \\
\text { simulation } 2\end{array}$ \\
\hline Parameter & $\begin{array}{c}\text { No pumping stress, } \\
\text { areal recharge = } \\
4.2 \mathrm{in} / \mathrm{yr}\end{array}$ & $\begin{array}{l}\text { Hypothetical } \\
\text { pumping, areal } \\
\text { recharge = } \\
4.2 \mathrm{in} / \mathrm{yr}\end{array}$ & $\begin{array}{l}\text { Hypothetical } \\
\text { pumping, areal } \\
\text { recharge = } \\
2.1 \mathrm{in} / \mathrm{yr}\end{array}$ \\
\hline
\end{tabular}

Sources (percent of total)

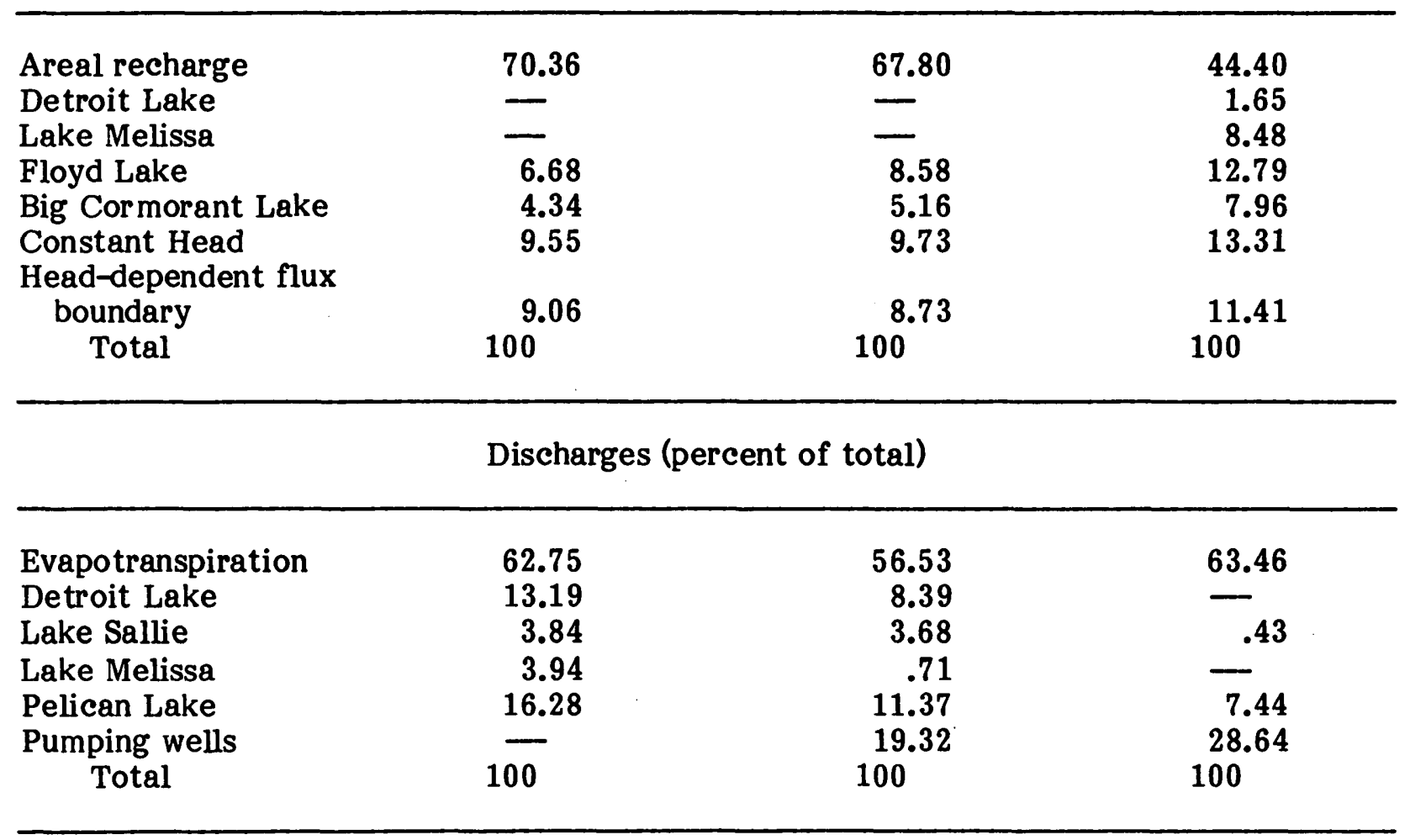

The models are now available for use in evaluating plans for large-scale development of ground-water supplies. The simulations of hypothetical ground-water development presented here are used to illustrate possible long-term effects on ground-water levels and lakes. No account is made in the models for annual variations in climate, lake levels, and withdrawal rates, all of which affect the aquifer system. The models can be easily updated and can be used to evaluate other plans for ground-water development, changes in the stresses on the aquifer system, or changes in other hydrologic factors affecting the aquifer system. 
Use of the models as presently configured is limited to steady-state simulations. This means that estimated drawdowns for some simulations may be misleading, as the length of time required to reach steady-state conditions may not be realistic. The simulations could be made more realistic by collecting and incorporating data on specific yield of the aquifer and by simulating known pumping and recharge times. However, steady-state models simulate worst-case drawdowns and, therefore, are extremely useful for planning.

\section{Sensitivity analysis}

Sensitivity values can be used to examine the effect of model-input parameters on model-computed hydraulic heads and recharge-discharge sources. When numerical models such as those previously described are used to predict changes in water levels due to natural or artificial stresses in the ground-water-flow system, it is important to know exactly which model parameters are most significant in specific model areas. This can be accomplished by comparing the areas of predicted head change with maps of individual parameter sensitivity. If an area of particular concern is also one with high sensitivity for one or more model-input parameters, the user of the model must define that parameter in that area more precisely than elsewhere to assure an accurate simulation. Users of ground-water models may not all have the technical background necessary to properly evaluate hydrogeologic data for a particular parameter. However, the model user should be aware of which specific parameter most critically affects the final computed heads.

Parameter sensitivity at individual model nodes (or grid blocks) is defined as the sum of the initial hydraulic head minus the computed hydraulic head resulting from the new parameter, divided by the quantity of the initial model parameter minus the new model parameter, divided by the initial model parameter. The mathematical equation (Beck and Arnold, 1977) describing individual nodal sensitivities is:

$$
S i=\sum_{i=1}^{n} \frac{\Delta H i}{\Delta P i / P i}
$$

where

$$
\begin{aligned}
S i & =\text { individual nodal sensitivity, } \\
\Delta H i & =H i-H N i, \\
\Delta P i & =P i-P N i, \\
H i & =\text { initial head, } \\
H N i & =\text { computed head resulting from new parameter, } \\
P i & =\text { initial parameter, } \\
P N i & =\text { new parameter, and } \\
i & =1,2,3 \ldots n, \text { where } n \text { is the total number of model nodes. }
\end{aligned}
$$


Dividing the denominator of the equation through by the initial parameter ( $i$ ) reduces the dimensions of sensitivity to units of head (such as feet or meters) and allows the sensitivities for parameters of different dimensions to be compared.

From equation 1 it is seen that changes in each input parameter $(P i)$ are compared with the corresponding change in model-computed hydraulic-head change. Note that the sensitivity value calculated is an indication of how an individual parameter will affect the hydraulic head calculated at that specific nodal point in the model grid. If these nodal sensitivity points are used to generate contours of sensitivity for an individual parameter, then relative sensitivities can be compared across the model area. Areas of relatively high sensitivity values should be recognized as areas where changes in the value of the parameter will significantly affect the model-computed hydraulic heads.

Plate 3 shows contours of sensitivity calculated by equation 1 for the model-input parameters of hydraulic conductivity, recharge, evapotranspiration, and the leakage term for head-dependent-flux boundaries. The sensitivity contours for hydraulic conductivity, recharge, and evapotranspiration represent a 100 percent increase in each new parameter from the initial parameter. Sensitivity contours of the leakage parameter represent a decrease of three orders of magnitude in the value of the new parameter. The percentage of parameter change used when calculating sensitivities is not critical because the model uses linear techniques to approximate nonlinear equations. Therefore, the sensitivity calculated for a 100-percent change would be twice that of a 50-percent change. The 100-percent change was used for the first three parameters to reduce the numerator of the sensitivity equation to unity and to simplify resulting calculations. The threeorders-of-magnitude change used for the leakage parameter was necessary to obtain sensitivities in the lake and lateral-boundary areas. As an equal percentage of change was used for the input parameters of hydraulic conductivity, areal recharge, and evapotranspiration, the relative sensitivity of these three may be compared. Positive values of sensitivity indicate decreases in head values, and negative values indicate increases in computed head values.

The response of model-computed heads to changes in hydraulic conductivity are shown in terms of sensitivity on plate 3. The hydraulic-conductivity parameter is generally more sensitive near the lateral boundaries of both models, where values of hydraulic conductivity are relatively low. Areal-recharge values (pl. 3) are also most sensitive in areas where the hydraulic conductivity is low and in areas with little loss through evapotranspiration.

Ground-water evapotranspiration (pl. 3) is a sensitive parameter near Detroit Lake and in the northern part of the Scambler model. The sensitive areas are where the water table is within 5 feet of land surface and where values of hydraulic conductivity are lower than in the surrounding area.

The leakage parameter has a low sensitivity except along the lateral model boundary west of Lake Sallie. Simulated heads increase west of Detroit Lake because the leakage parameter is controlling the rate of lateral recharge into the model area, and a higher leakage rate allows more water through this boundary. Sensitivity values on the southern boundary of the Scambler model represent an area where ground water is moving out of the model area. An increase in the leakage rate allows more water to leave, thus lowering simulated water levels. 
The area most sensitive to hydraulic conductivity, areal recharge, and ground-water evapotranspiration is the northern part of the Scambler model. Here values of hydraulic conductivity are relatively low, and simulated water levels are within 5 feet of land surface. The numerical model should be used with caution to evaluate the effects of pumping in this specific area. Additional data collection may be necessary to obtain more accurate model simulations, depending on the use of the model and the accuracy requirements of the model user.

\section{BURIRD AQUIFERS}

Buried aquifers underlie the area. The areal extent of these aquifers is not known because of lack of test-hole or well-log data and the cost of exploratory drilling. One irrigation well at $137 \mathrm{~N} 43 \mathrm{~W} 15 \mathrm{ACB}$ pumps from a buried aquifer. At this location, the unconfined aquifer consists of uniform fine sand that grades slightly toward medium sand at the base. The confining layer is a heterogeneous mixture of clay to coarse sand containing a few thin clay layers. The confined aquifer consists of medium to coarse sand with some thin layers of fine sand.

An aquifer test on the irrigation well was made to examine the effects on the water table of pumping from the buried aquifer (Miller, 1980). Figure 14 shows the location and depth of observation wells with respect to the pumping well, and an idealized hydrologic section of the test site. Drawdown data for the 48-hour test, analyzed by the methods described by Lohman (1972), indicated a transmissivity of $19,900 \mathrm{ft}^{2} / \mathrm{d}$ and a storage coefficient of $3.5 \times 10^{-4}$ for the confined aquifer. Using the methods for nonsteady radial flow in an infinite leaky confined aquifer (Lohman, 1972), a value of $0.0181 \mathrm{ft} / \mathrm{d}$ was obtained for the vertical hydraulic conductivity of the overlying confining bed. During the test, there was no effect on the hydraulic head in the unconfined aquifer.

Results from one test of the confined aquifer cannot be applied to all confined aquifers within the area. The effect on an unconfined aquifer of pumping from a confined aquifer is best defined independently for any new wells by the methods and procedures previously outlined. As more information becomes available on the areal extent and hydrogeologic properties of buried aquifers, management tools similar to the model of the unconfined aquifer can be developed for more critical evaluation.

\section{SUMMARY}

The surficial aquifer of the Pelican River sand-plain area, in west-central Minnesota, comprises approximately $200 \mathrm{mi}^{2}$ of glacial outwash sand and gravel. The aquifer generally ranges from 0 to 80 feet in thickness and locally is as thick as 140 feet. Grain size ranges from fine to coarse sand. The aquifer is bounded by a relatively impermeable heterogeneous mixture of clay, silt, and sand- and gravel-size material known as till.

Recharge to the ground-water system is mainly through infiltration during spring snowmelt and rains. Calculated recharge by infiltration ranged from 3.7 to 6.1 inches in 1979 and 3.2 to 5.9 inches in 1980. Recharge from movement of ground water across lateral boundaries was calculated to be 0.39 inch for 1979 and 0.34 inch for 1980 .

Loss of water from the ground-water-flow system is mainly through evapotranspiration and discharge to the Pelican River. The average annual evapotranspiration is 22.4 inches per year. 


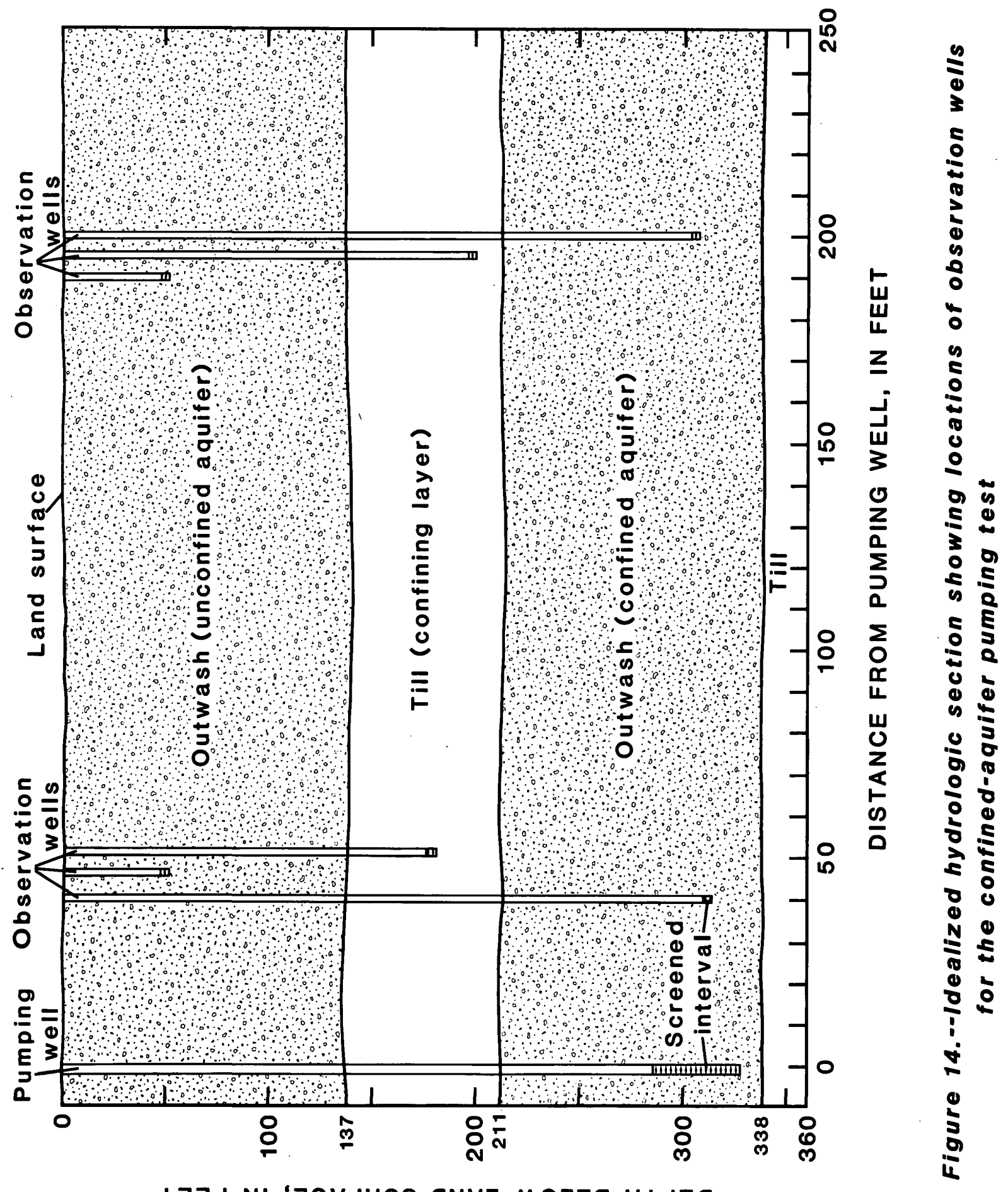

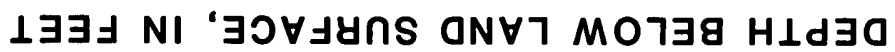


The primary hydraulic characteristics of the surficial aquifer are the transmissivity and saturated thickness. Saturated thickness ranged from 20 to $60 \mathrm{feet}$, byt is greater than 100 feet locally. Transmissivity generally ranged from 100 to $7,500 \mathrm{ft}^{2} / \mathrm{d}$, but is as much as $12,500 \mathrm{ft}^{2} / \mathrm{d}$ locally.

Theoretical optimum well yields can be estimated if both the saturated thickness and transmissivity are known. Theoretical well yields ranged from 40 to as much as $1,200 \mathrm{gal} / \mathrm{min}$.

The chemical quality of the water in the area is generally suitable for irrigation as measured by sodium-adsorption ratios. Dissolved solids in the ground water consist predominantly of calcium, magnesium, and bicarbonate ions that, if present in large amounts, may cause well-screen incrustation. Salt accumulation in the root zone of the soil is not a problem at present, but soil-salinity monitoring may be warranted if irrigation increases.

An analytical model used to examine the effects of hypothetical pumping on flow of the Pelican River from Pelican Rapids to south of Elizabeth, Minn., indicates that wells near the Pelican River can obtain a significant percentage of their water from the river. The potential decrease in streamflow is dependent on the number of pumping wells, pumping rates, time of pumping, and distance of the pumping wells from the Pelican River.

A numerical model used to examine the effect of long-term hypothetical pumping on ground-water levels and the potential effects on lakes indicates that under normal recharge conditions, water levels may decline 8 feet locally. For the same hypothetical pumping conditions with half the normal recharge, water levels may locally decline 20 feet. For both recharge conditions, the ground water discharging into lakes was decreased, indicating a potential drop in lake levels.

Sensitivity analyses of model-input parameters of hydraulic conductivity, recharge, evapotranspiration, and leakage shows areas where these parameters significantly affect model-computed head. The northern part of the Scambler model, where values of hydraulic conductivity are low and simulated water levels are within 5 feet of land surface, is sensitive to all the above parameters except leakage, and is an area where additional data could improve the accuracy of the simulations.

Buried aquifers underlie the area, but lack of data and the cost of exploratory drilling prohibits mapping their extent. Analysis of data from one aquifer test indicates a transmissivity of $19,900 \mathrm{ft}^{2} / \mathrm{d}$ and a storage coefficient of $3.5 \times 10^{-4}$. Pumping from the irrigation well completed in the buried aquifer had no effect on water levels in the overlying surficial aquifer.

\section{REPERENCES}

Allison, I. S., 1932, The geology and water resources of northwestern Minnesota: Minnesota Geological Survey Bulletin 22, 245 p.

Beck, J. V., and Arnold, K. J., 1977, Parameter estimation in engineering and science: New York, John Wiley, 501 p.

Davis, S. N., and DeWiest, R. J. M., 1966, Hydrogeology: New York, John Wiley, 463 p. 
Fenneman, N. M., 1938, Physiography of eastern United States: New York, McGraw-Hill, 714 p.

Ferris, J. G., Knowles, D. B., Brown, R. H., and Stallman, R. W., 1962, Theory of aquifer tests: U.S. Geological Survey Water-Supply Paper 1536-E.

Freeze, R. A., and Witherspoon, P. A., 1966, Theoretical analysis of regional groundwater flow: 1. Analytical and numerical solutions to the mathematical model: Water Resources Research, v. 2, no. 4., p. 641-656.

Gates, J. S., 1971, Worth of data used in digital-computer models of ground-water basin: University of Arizona, Technical Reports on Hydrology and Water Resources, Technical Report 8, 214 p.

Jacob, C. E., 1944, Notes on determining permeability by pumping tests under watertable conditions: U.S. Geological Survey Bulletin 41, 193 p.

Johnson, E. E., Inc., 1966, Groundwater and wells: St. Paul, Minn., Edward E. Johnson, Inc., $440 \mathrm{p}$.

Kohler, M. A., Nordenson, T. J., and Baker, D. R., 1959, Evaporation maps of the United States: U.S. Weather Bureau Technical Paper 37, 13 p.

Larson, S. P., 1976, An appraisal of ground water for irrigation in the Appleton area, west-central Minnesota: U.S. Geological Survey Water-Supply Paper 2039-B, 34 p.

Larson, S. P., McBride, M. S., and Wolf, R. J., 1975, Digital models of a glacial outwash aquifer in the Pearl-Sallie Lakes area, west-central Minnesota: U.S. Geological Survey Water-Resources Investigations 40-75, 39 p.

Leverett, Frank, 1932, Quaternary geology of Minnesota and parts of adjacent States, with contributions by F. W. Sardenson: U.S. Geological Survey Professional Paper 161,149 p.

Lindholm, G. F., 1980, Ground-water appraisal in Benton, Sherburne, Stearns, and Wright Counties, central Minnesota: U.S. Geological Survey Water-Resources Investigations 80-1285, 103 p.

Lindskov, K. L., 1977, Low-flow characteristics of Minnesota streams: U.S. Geological Survey Water-Resources Investigations 77-48, $197 \mathrm{p}$.

Lohman, S. W., 1972, Ground-water hydraulies: U.S. Geological Survey Professional Paper 708.

Mann, William B., IV, and McBride, Mark S., 1972, The hydrologic balance of Lake Sallie, Becker County, Minnesota: U.S. Geological Survey Professional Paper 800-D, p. D189-D191.

McBride, M. S., and Pfannkuch, H. O., 1975, The distribution of seepage within lakes: U.S. Geological Survey Journal of Research, v. 3, p. 505-512. 
Meyer, C. F., 1971, Using experimental models to guide data gathering: American Society of Civil Engineers, Journal of Hydraulics, v. 97, HY10, p. 1681-1697.

Miller, R. T., 1980, Hydrogeologic data for the Pelican River sand-plain aquifer, western Minnesota: U.S. Geological Survey Open-File Report 80-696, 89 p.

Minnesota Department of Conservation, 1968, An inventory of Minnesota Lakes: Division of Water, Soils, and Minerals Bulletin 25, 498 p.

Minnesota Water Pollution Control Commission, 1967, Water-quality standards for the interstate waters of Minnesota: $174 \mathrm{p}$.

National Academy of Sciences, National Academy of Engineering, 1973, 1974, Waterquality criteria, 1972: U.S. Environmental Protection Agency, EPA R3-73-033, 594 p.

Norvitch, R. F., Ross, T. G., and Brietkrietz, Alex, 1974, Water-resources outlook for the Minneapolis-St. Paul metropolitan area, Minnesota: Metropolitan Council of the Twin Cities, 219 p.

Pinder, G. F., and Bredehoeft, J. D., 1968, Application of the digital computer for aquifer evaluation: Water Resources Research, v. 4, no. 5, p. 1069-1093.

Reeder, H. O., 1972, Availability of ground water for irrigation from glacial outwash in the Perham area, Otter Tail County, Minnesota: U.S. Geological Survey Water-Supply Paper 2003, 45 p.

Stephenson, D. A., 1971, Ground-water flow system analysis in lake environments, with management and planning implications: Water Resources Bulletin, v. 7, no. 5, p. 1038-1047.

Theis, C. V., 1935, The relation between the lower of the piezometric surface to the rate and duration of a well using ground-water storage: American Geophysical Union Transaction, v. 16, pt. 2, p. 519-524.

1941, The effect of a well on the flow of a nearby stream: American Geophysical Union Transaction, v. 22, pt. 3, p. 734-738.

19631964 , Chart for the computation of drawdowns in the vicinity of a discharging well, in Bentall, Ray, compiler, Shortcuts and special problems in aquifer tests: U.S. Geological Survey Water-Supply Paper 1545-C, p. C10-C15.

Thornthwaite, C. W., and Holman, B., 1939, The determination of evaporation from land and water surfaces: Monthly Weather Review 67, p. 4-11.

Trescot, P. C., Pinder, F. G., and Larson, S. P., 1976, Finite-difference model for aquifer simulation in two-dimensions with results of numerical experiments: U.S. Geological Survey Techniques of Water-Resources Investigations, Book 7, Chapter C1, 116 p.

Upham, Warren, 1888, Geology of Minnesota: Minnesota Geological and Natural History Survey Final Report, v. 2, p. 534-561. 
University of Minnesota, U.S. Soil Conservation Service, Minnesota Geological Survey, 1969, Soil landscapes and geomorphic regions - Brainerd sheet.

U.S. Salinity Laboratory, 1954, Diagnosis and improvement of saline and alkali soils: U.S. Department of Agriculture, Agriculture Handbook 60.

Veihmeyer, T. J., 1964, Evapotranspiration, in Chow, Van Te (ed.), Handbook of applied hydrology: New York, McGraw-Hill, p. 11-8, 11-9.

Walton, W. C., 1970, Ground-water resources evaluation: New York, McGraw-Hill, p. 314-318.

Winter, T. C., Bidwell, L. E., and Maclay, R. W., 1969, Water resources of the Otter Tail River watershed, west-central Minnesota: U.S. Geological Survey Hydrologic Investigations Atlas HA-296.

Wright, H. E., Jr., and Ruhe, R. V., 1965, Glaciation of Minnesota and Iowa in Wright H. E., Jr., and Frey D. G. (eds.), The Quaternary of the United States: Princeton, New Jersey, University of Princeton Press, p. 29-41. 